\title{
Wpływ oparów metalicznych na spawanie łukowe, część 2: Obliczanie
}

\section{The effects of metal vapour in arc welding, part 2: Calculation}

\section{Streszczenie}

W części 2 artykułu omówiono sposoby modelowania i obliczania parametrów łuku spawalniczego w metodach TIG i MIG/MAG. Przedstawiono również metodykę prowadzenia obliczeń właściwości termodynamicznych, współczynników przenoszenia i współczynników dyfuzji.

\section{Abstract}

This part is concerned with computational modelling of welding arcs and the influence of metal vapour. Methods used in modelling, including equations, transport properties, treatment of metal vapour diffusion, radiative emission coefficients and vaporization rates are presented.

\section{Metody modelowania matematycznego łuku spawalniczego}

\section{Równania}

Obliczeniowe modelowanie plazmy w łuku spawalniczym oparte jest na komplecie sprzężonych równań różniczkowych cząstkowych wyrażających zachowanie masy, pędu, energii i ładunku. Poniżej przytoczono równania w typowej postaci z członami: zależnym od czasu i konwekcyjnym po lewej stronie oraz członami: dyfuzyjnym i źródła po prawej stronie równania.

Równanie na ciągłość masy:

$$
\frac{\partial \rho}{\partial t}+\nabla \cdot(\rho \underset{v}{v})=0
$$

gdzie: $p$-gęstość masy, $\stackrel{v}{-}$ - prędkość przepływu, $t$ - czas.

Równanie na zachowanie pędu:

$$
\frac{\partial(\rho \underline{v})}{\partial t}+\nabla \cdot(\rho \underline{v} \underline{v})=-\nabla P+\nabla \cdot \underline{\tau}+\underline{j} \times \underline{B}+\rho \underline{g}
$$

gdzie: $P$ - ciśnienie, $\stackrel{\tau}{\tau}$-tensor naprężeń, $j$-gęstość prądu, $\underline{B}$ - indukcja pola magnetycznego, $g$ - przyspiesżenie ziemskie.

Anthony B. Murphy - CSIRO Materials Science and Engineering, Australia.
Człony po prawej stronie opisują odpowiednio: siły spowodowane gradientem ciśnienia, naprężeniem lepkim, siłę magnetyczną (Lorentza) oraz siłę grawitacji.

Równanie na zachowanie energii:

$$
\frac{\partial(\rho h)}{\partial t}+\nabla \cdot(\rho \underline{v} h)=\frac{\underline{j}^{2}}{\sigma}-U+\nabla \cdot\left(\frac{k}{c_{p}} \nabla h\right)+\frac{5 k_{\mathrm{B}}}{2 e c_{p}} j \cdot \nabla h
$$

gdzie: $h$ - entalpia, $\sigma$ - przewodność elektryczna, $U$ - wypadkowy współczynnik emisji promieniowania, $k$ - przewodność cieplna, $c_{P}$ - ciepło właściwe przy stałym ciśnieniu, $k_{B}$ - stała Boltzmanna, $e$ - wartość ładunku elektronu.

Wyrażenia po prawej stronie opisują odpowiednio: grzanie oporowe, emisję promieniowania, przewodność cieplną oraz przekaz energii wynikający z przepływu elektronów. Entalpia jest całką ciepła właściwego po temperaturze, a temperaturę w dowolnym punkcie można obliczyć z entalpii w tym właśnie punkcie. Metoda wypadkowego współczynnika emisji promieniowania jest powszechnie stosowana do przenoszenia promieniowania. Jeśli stosowana jest inna metoda, wówczas człon na emisję promieniowania we wzorze (3) musi zostać zmieniony.

Równanie na ciągłość prądu:

$$
\nabla \cdot(\sigma \nabla \phi)=0
$$

gdzie: $\phi$ - potencjał elektryczny. 


\section{Gęstość natężenia prądu jest dana wzorem}

$$
\underset{\sim}{j}=-\sigma \nabla \phi
$$

Indukcja pola magnetycznego $B$, która pojawia się we wzorze (2), także musi być obliczona, np. ze wzoru na potencjał pola magnetycznego $A$ :

$$
\nabla^{2} \underset{\sim}{A}=-\mu_{0} \underset{\sim}{j}
$$

gdzie: $\underline{B}=\nabla \times A$.

W spawaniu łukowym z gazem osłonowym i oparami metalicznymi potrzebne jest również równanie wyrażające zachowanie masy oparów metalicznych. Zazwyczaj zakłada się, że plazma zawiera dwa osobne składniki: opary metaliczne i gaz osłonowy. Dlatego substancje pochodzące od oparów metalu (np. Fe, $\mathrm{Fe}^{+}$, $\mathrm{Fe}^{2+}, \mathrm{Fe}^{3+}$ itd. dla oparów żelaza) są traktowane jako jeden gaz, a te od gazu osłonowego (np. Ar, $\mathrm{Ar}+, \mathrm{Ar}^{2+}$, $\mathrm{Ar}^{3+}$ itd. dla argonu) jako inny gaz. Elektrony są podzielone pomiędzy dwa gazy, więc każdy z nich jest elektrycznie neutralny. Równanie dla zachowania masy oparów metalicznych wygląda wówczas następująco:

$$
\frac{\partial \rho \overline{Y_{\mathrm{M}}}}{\partial t}+\nabla \cdot\left(\rho \underline{\underline{Y_{\mathrm{M}}}}\right)=-\nabla \cdot \overline{J_{\mathrm{M}}}+S_{\mathrm{M}}
$$

gdzie: $\overline{Y_{\mathrm{M}}}$-suma ułamków wagowych substancji oparów metalu, $\overline{J_{\mathrm{M}}}$ - średni przepływ masy $w$ stosunku do średniej prędkości masy substancji oparów metalu, $S_{M}$ - człon źródłowy oparów metalicznych (masa na jednostkę objętości i czasu).

Pierwszy człon po prawej stronie opisuje dyfuzję oparów metalicznych, a drugi powstanie oparów metalicznych w wyniku odparowania elektrod, z uwzględnieniem możliwych strat, np. skraplania oparów metalu.

Dodatkowe wyrażenie:

$$
-\nabla \cdot\left[\left(\overline{h_{\mathrm{M}}}-\overline{h_{\mathrm{G}}}\right) \frac{k}{c_{p}} \nabla \overline{Y_{\mathrm{M}}}\right]
$$

dodaje się do prawej strony wzoru na zachowanie energii (3), by uwzględnić zmianę entalpii wynikającą z mieszania oparów metalu i gazu osłonowego; $\overline{h_{\mathrm{M}}}$ i $\overline{h_{\mathrm{G}}}$ to entalpie odpowiednio oparów metalu i gazu osłonowego, zdefiniowane jako sumy entalpii substancji tworzących poszczególne gazy. Należy zwrócić uwagę, że w pracach $[59,84]$ został uwzględniony dodatkowy człon w $\bar{J}_{\mathrm{M}}$, przy czym człon ten został już zawarty w przewodności cieplnej [85].

Człon źródła oparów metalicznych we wzorze (6) powinien być także dodany do prawej strony równania na zachowanie masy (1). Należy do niego również dodać człon odpowiedzialny za chłodzenie wyparne (3).

Równania te rozwiązuje się zazwyczaj, stosując metodę objętości skończonych [86], pomimo że coraz częściej do tworzenia modeli plazm termicznych stosowane są metody elementów skończonych.

Właściwości plazmy termicznej silnie zależą od właściwości termofizycznych gazu plazmy, które występują we wzorach (1) i (7). Właściwości te mogą być podzielone na termodynamiczne (gęstość, ciepło właściwe, entalpia), współczynniki przenoszenia (lepkość, przewodność elektryczna, przewodność cieplna, współczynniki dyfuzji) oraz współczynniki emisji promieniowania. Obecność oparów metalicznych ma wpływ na wszystkie z wymienionych właściwości, jednak najbardziej zmienia przewodność elektryczną i współczynniki emisji promieniowania. Znajomość współczynników dyfuzji jest wymagana do obliczenia strumienia masy oparów metalicznych i wraz z przepływem konwekcyjnym określają one rozkład oparów metalicznych w łuku. Właściwości termodynamiczne, transportu i promieniowania oraz współczynniki dyfuzji będą omówione w dalszej części artykułu.

Konieczne jest również dobranie odpowiedniej metody wyznaczenia szybkości parowania metalu z elektrod (człon źródłowy we wzorze (6)).

\section{Obliczenie właściwości termodynamicznych i współczynników przenoszenia}

Punktem wyjścia do obliczeń tych właściwości jest określenie składu plazmy. Jeśli założono istnienie stanu LTE (z ang. Local Thermal Equilibrium - Lokalna Równowaga Termodynamiczna), to skład plazmy można określić, rozwiązując równania Sahy dla procesów jonizacji oraz równania Guldberga-Waage'a dla reakcji dysocjacji, bądź przez zminimalizowanie swobodnej energii Gibbsa plazmy [87]. Dla plazm niebędących w stanie LTE nadal poszukuje się właściwych metod [36].

Właściwości termodynamiczne są stosunkowo łatwe do obliczenia. Kiedy znamy skład plazmy, potrzebne są tylko dane dotyczące zależności ciepła właściwego każdej substancji od temperatury. Dane te dostępne są w tablicach (np. [88]) lub mogą być wyliczone z danych spektroskopowych. Aby obliczyć współczynniki przenoszenia, niezbędne jest skorzystanie z całek zderzeniowych cząstek pomiędzy wszystkimi oparami występujących substancji, przy czym uzyskanie dokładnych wartości może być trudne $[87,89]$. Całki zderzeniowe to przekroje zderzeniowe uśrednione po maxwellowskim rozkładzie energii, wyprowadzone z potencjału międzyatomowego i innych podstawowych danych.

Pomimo że opublikowane zostały wiarygodne dane współczynników przenoszenia dla większości gazów plazmowych (np. argonu, azotu, tlenu [90, 91], powietrza [92, 93], helu [94] i wodoru [95]) oraz wielu mieszanin tych gazów $[90,92,94 \div 96]$, nie ma danych dla większości oparów metalicznych. Jest to częściowo spowodowane tym, że nie są one w centrum zainteresowania, a częściowo z powodu braku dokładnych danych całek zderzeniowych w przypadku oddziaływania pomiędzy drobinami metalu oraz pomiędzy drobinami metalu a innymi cząstkami. Najbardziej skomplikowane potencjały międzyatomowe, które zostały zastosowane 
w obliczeniach plazmy, opracowano dla mieszaniny argonu z miedzią [97] oraz mieszaniny srebra z dwutlenkiem krzemu [98]. W pracach tych do obliczenia całek zderzeniowych w przypadku oddziaływania pomiędzy neutralnymi drobinami metalu zastosowano potencjał Hulburta-Hirschfeldera $[99 \div 101]$. W innych pracach wykorzystano potencjał Morse'a dla oddziaływania po-

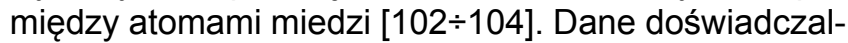
ne pomogły w obliczeniu całek zderzeniowych dla par jon-cząstka neutralna oraz elektron-cząstka neutralna dla miedzi [97]. Z kolei dla całek zderzeniowych krzemu i srebra dostępne były jedynie wartości przybliżone oraz wzory empiryczne.

Hoffmann w obliczeniach właściwości mieszanin żelaza, miedzi, aluminium i wapnia z azotem, argonem i helem, posłużył się potencjałem Stockmayera $(12,6$, 3) dla oddziaływania cząstka neutralna - cząstka neutralna oraz potencjałem oddziaływań elastycznych pomiędzy cząstkami neutralnymi a jonami $(16,6,4)$ [105]. Słabym punktem tej pracy było założenie, że ciepło właściwe substancji było stałe w wysokiej temperaturze oraz użycie przybliżonych danych termodynamicznych dla wielokrotnie zjonizowanych substancji.

W innych obliczeniach posłużono się przybliżonymi potencjałami międzyatomowymi, takimi jak potencjał Lennarda-Jonesa $(12,6)$ dla oddziaływań między drobinami neutralnymi, wzorami empirycznymi [106] dla oddziaływań z wymianą ładunku pomiędzy atomami i jonami tego samego metalu oraz potencjałem polaryzacyjnym dla zderzeń elastycznych pomiędzy drobinami neutralnymi i jonami. Na przykład, Cressault [107] zastosował przybliżenia do określenia właściwości plazmy w mieszaninach powietrza z żelazem, srebrem i miedzi, podobnie jak zrobili to: Dunn i Eagar [108] dla mieszaniny argonu lub helu z żelazem, aluminium lub wapniem; Gu [109] do obliczenia właściwości plazmy w mieszaninach argonu i oparów krzemu; Abdelhakim [110] dla plazmy z mieszaniny miedzi i azotu; Dassanayake i Etemadi [111] dla plazmy azotowo-aluminiowej.

W tej pracy obliczono właściwości termodynamiczne i warunki przenoszenia w mieszaninach argonu z żelazem, aluminium, chromem i oparami manganu. Przybliżenia, o których wspomniano wcześniej, zostały zastosowane w obliczeniach oddziaływań atomów metalu. Całki zderzeniowe dla oddziaływań elektron-atom obliczono przez całkowanie pędu przekroju czynnego na przekaz pędu, który uzyskano dzięki przybliżeniu efektywnego zasięgu dla małych energii zderzenia oraz przybliżeniu klasycznemu dla dużych energii zderzeń [112]. W przypadku oddziaływań pomiędzy drobinami argonu zastosowano metody Murphy'ego i Arundella [90], co opisano również w pracy Yanga [19].
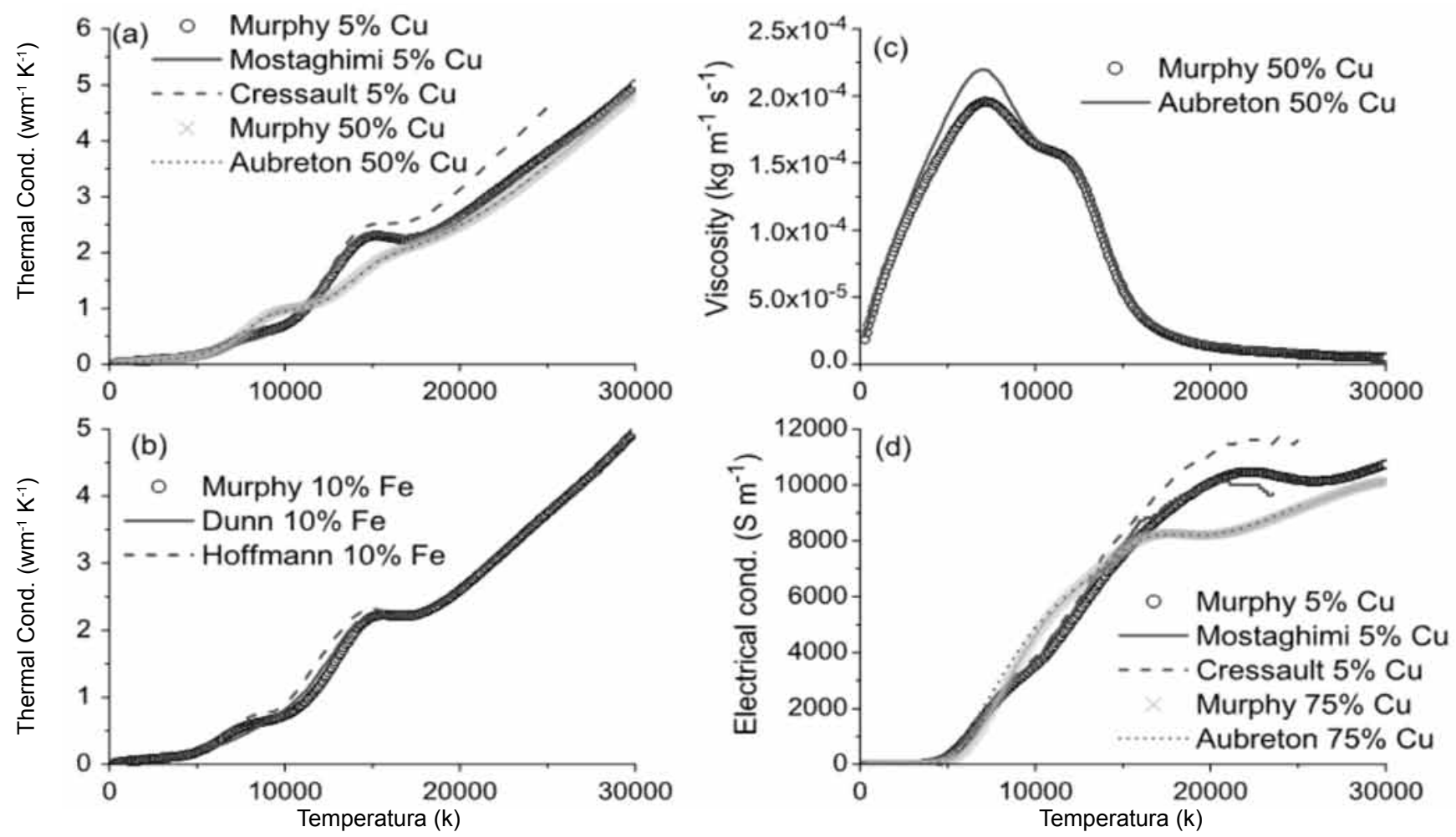

Rys. 6. Porównanie parametrów transportu w plazmie argon-miedź oraz argon-żelazo, obliczonych przez różnych autorów (procenty na mol). a) przewodność cieplna mieszaniny argon-miedź; b) przewodność cieplna mieszaniny argon-żelazo; c) lepkość mieszaniny argon-miedź; d) przewodność elektryczna mieszaniny argon-miedź. Dane dla mieszaniny argon-miedź pochodzą z [97, 102 -104], a dla argon-żelazo z $[19,105,108]$

Fig. 6. Comparison of transport properties of argon-copper and argon-iron plasmas calculated by different authors. Percentages are by mole: a) Thermal conductivity of argon-copper mixtures; b) thermal conductivity of an argon-iron mixture; c) viscosity of an argon-copper mixture; d) electrical conductivity of argon-copper mixtures. References from which the data were taken are for argon-copper [97, 102 $\div 104]$ nad for argon-iron [19, 105, 108] 
Na rysunku 6 przedstawiono porównanie współczynników transportu obliczonych przez różnych autorów. Podane wyniki dotyczą mieszanin argonu, żelaza i oparów miedzi. Ogólnie, opublikowane wartości przewodności cieplnej i elektrycznej dla mieszanin argonu i miedzi są zgodne. Największa rozbieżność pojawia się przy temperaturze powyżej $13000 \mathrm{~K}$, gdzie wartości podane przez Cressaulta i Gleizesa [104] są większe od wartości uzyskanych przez pozostałych badaczy. Jest to spowodowane mniejszą wartością przekroju Coulomba, prawdopodobnie wynikającą z uwzględnienia zarówno jonów, jak i elektronów zamiast tylko elektronów w obliczeniach promienia Debye'a. Ta kwestia została omówiona bardziej szczegółowo w pracy [95].

Dane dla przewodności cieplnej mieszaniny argonu i żelaza zmieniają się między 5000 i $14000 \mathrm{~K}$. Maksima występują przy ok. 7000 i 14000 K, co odpowiada zmianie przewodności cieplnej związanej z pierwszą jonizacją odpowiednio miedzi i argonu. Wartości te są nieco przesunięte w obliczeniach Hoffmanna [105]. Prawdopodobnie jest to spowodowane przybliżeniem danych termodynamicznych, co mogło prowadzić do niedokładności wyznaczenia temperatury jonizacji. W pracy Dunna i Eagara brakuje pierwszego maksimum [108].

Lepkość wyznaczona przez Aubretona i Elchingera [97] jest o ok. 10\% większa niż u Murphy'ego [103] dla temperatury ok. $7000 \mathrm{~K}$. W tej temperaturze dominuje przekrój czynny na zderzenia elastyczne atomów i jonów. Murphy posłużył się przekrojem polaryzacyjnym dla oddziaływania $\mathrm{Cu}-\mathrm{Cu}^{+}$, z kolei Aubreton i Elchinger użyli danych eksperymentalnych z pracy Witko i Beckmanna [113] dla stanu ${ }^{2} \Sigma_{\mathrm{g}}$ oraz procedury dopasowania w celu obliczenia potencjału dla stanu ${ }^{2} \Sigma_{u}$, która wydaje się dokładniejsza.

Na rysunku 6 pokazano, że różnice pomiędzy współczynnikami transportu miedzi Aubretona i Elchingera, obliczonymi za pomocą bardziej skomplikowanych przekrojów czynnych na oddziaływania pomiędzy drobinami miedzi a współczynnikami obliczonymi przy użyciu przybliżonych przekrojów czynnych, są względnie małe. Przypuszcza się, że przybliżone metody użyte dla większości innych oparów metalicznych mają podobny poziom dokładności. Jednak, jako przybliżenie oparte na obliczeniach dla różnych mieszanek gazów [2], dana zmiana wartości współczynnika transportu powoduje podobną względną zmianę parametrów spawania, takich jak rozkład strumienia przepływu ciepła na powierzchni jeziorka spawalniczego. Nie powinno nastręczać trudności rozwinięcie potencjałów Hulburta-Hirschfeldera dla innych metali, ponieważ parametry tych potencjałów można wyprowadzić ze stałych spektroskopowych. To poprawiłoby dokładność współczynników transportu i tym samym przewidywań opartych na modelowaniu.

Na rysunku 7 pokazano obliczoną zależność ciepła właściwego, przewodności cieplnej i elektrycznej oraz lepkości od koncentracji oparów żelaza w plazmie argonowej. Właściwości te ulegają znacznej zmianie po dodaniu $50 \%$ oparów żelaza, małe zmiany pojawiają się już przy $10 \%$. Tylko przewodność cieplna w przedziale 4000 $\div 10000 \mathrm{~K}$ ulega zmianie już w obecności
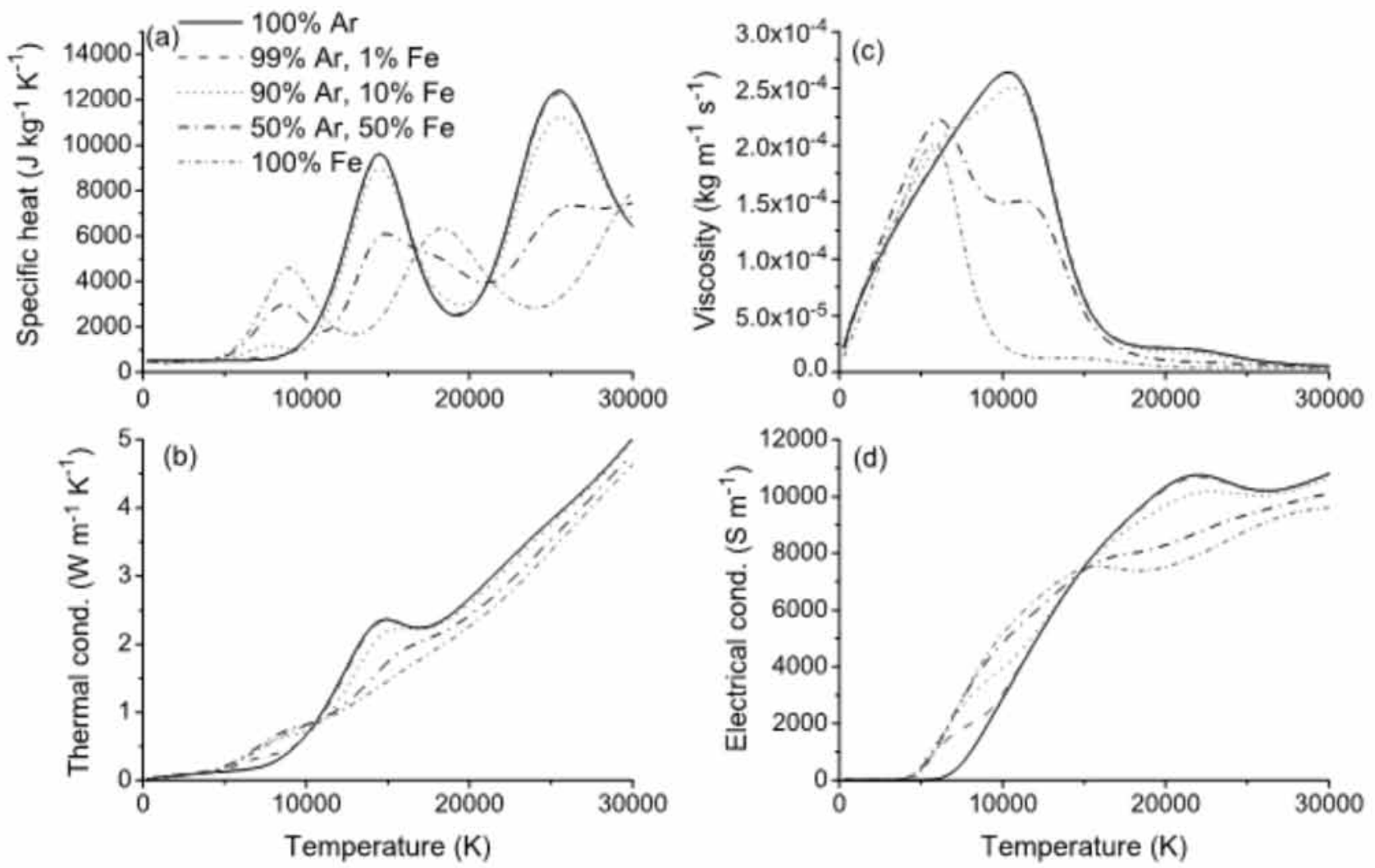

Rys. 7. Obliczone właściwości plazmy w różnych mieszaninach argonu i oparów żelaza. Procenty na mol (\%/mol)

Fig. 7. Calculated properties of plasmas in different mixtures of argon and iron vapour. Percentages are by mole 
1\% oparów żelaza. Wynika to z niższej energii jonizacji atomów żelaza.

Na rysunku 8 przedstawiono porównanie ciepła właściwego, przewodności cieplnej, przewodności elektrycznej oraz lepkości dla mieszanin argonu i różnych oparów metalicznych. Różnice są niewielkie, a najbardziej widoczne jest wyższe ciepło właściwe aluminium w wysokiej temperaturze oraz niższa przewodność elektryczna miedzi w temperaturze poniżej $10000 \mathrm{~K}$. Prawdopodobnie jednak przewodność elektryczna miedzi powinna być większa. Przekrój czynny na przekaz pędu w zderzeniach pomiędzy elektronami i atomami miedzi, który jest istotny $\mathrm{w}$ tym zakresie temperatury, został zaczerpnięty z pracy Chervy'ego [114]. Posłużył się on wartościami zmierzonymi przez Scheibnera [115] przy wysokich energiach oraz teoretycznymi wartościami Trajmara [116] przy niskich energiach. Tak, jak zostało to omówione w pracy Chervy'ego, wysokość maksimum przekroju czynnego na przekaz pędu przy niskiej energii jest istotna przy wyznaczeniu przewodności elektrycznej. W przypadku miedzi maksimum jest większe (ok. $390 \times 10^{-20} \mathrm{~m}^{2}$ ), niż to, które zostało obliczone metodami przybliżonymi dla innych metali, zawierające się w zakresie od $120 \times 10^{-20} \mathrm{~m}^{2}$ dla aluminium do $180 \times 10^{-20} \mathrm{~m}^{2}$ dla chromu. Prawdopodobnie wartości „przekroju czynnego na przekaz pędu” Scheibnera, którymi posłużył się Chervy, to w rzeczywistości całkowite przekroje czynne [97, 117]), a zatem są zbyt duże.

\section{Obliczanie współczynników dyfuzji}

Transport oparów metalicznych w łuku plazmowym następuje zarówno w wyniku konwekcji, jak i dyfuzji. Konwekcję opisuje drugi wyraz po lewej stronie równania (6) i nie wymaga to szczególnych objaśnień. Bardziej skomplikowana jest dyfuzja.

W najbardziej ogólnym podejściu do plazm zawierających więcej niż jeden pierwiastek chemiczny, równania na zachowanie masy dla poszczególnych drobin (np. $\mathrm{Ar}, \mathrm{Ar}^{+}, \mathrm{Fe}, \mathrm{Fe}^{+}, \mathrm{e}^{-}$):

$$
\frac{\partial \rho Y_{i}}{\partial t}+\nabla \cdot\left(\rho \underset{\sim}{v} Y_{i}\right)+\nabla \cdot \underset{\sim}{J}=r_{i}
$$

muszą być rozwiązane w każdym punkcie plazmy. $Y_{i}$ oznacza ułamek masowy składnika $i ; r_{i}$ szybkość netto produkcji cząstek $i$-tego rodzaju w wyniku reakcji chemicznych, parowania itp. Dla gazu lub plazmy zawierającej $N$ składników, dyfuzyjny strumień masy substancji $i, J_{-i}$ dany jest wzorem:

$$
J_{\sim} \equiv m_{i} n_{i}{\underset{\sim}{\sim}}_{i}=\frac{m_{i} n^{2}}{\rho} \sum_{j=1}^{N} m_{j} D_{i j} \underset{\sim j}{d}-D_{i}^{T} \nabla \ln T
$$

gdzie: $\underset{\sim}{v}$ - prędkość dyfuzji substancji $i$ (w stosunku do średniej prędkości masy), $m_{i}$ - masa, $n_{i}$ - koncentracja substancji $i$ [89].
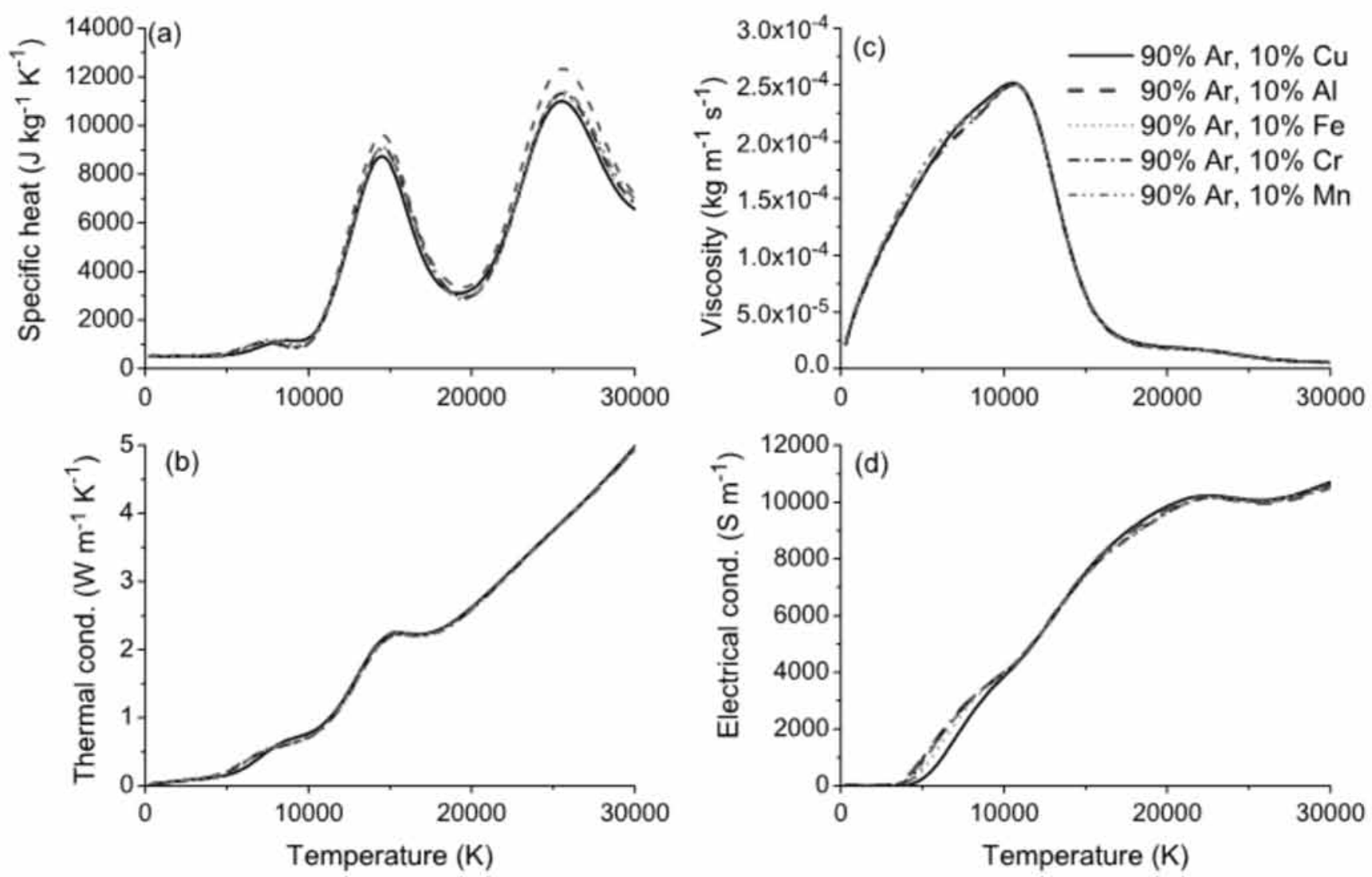

Rys. 8. Obliczone właściwości plazmy dla pięciu różnych metali w mieszaninie $90 \%$ argonu i 10\% oparów metalicznych

Fig. 8. Calculated properties of plasmas in mixtures of $90 \%$ argon and $10 \%$ metal vapour by mole, for five different metals 
Zwykłe współczynniki dyfuzji $D_{i j}$ oraz współczynniki dyfuzji termicznej $D_{i}^{T}$ są w tym przypadku współczynnikami dyfuzji wieloskładnikowej. Siła napędowa dana jest wzorem:

$d_{j}=\nabla x_{j}+\left(x_{j}-\frac{n_{j} m_{j}}{\rho}\right) \nabla \ln P-\frac{n_{j} m_{j}}{P \rho}\left(\frac{\rho}{m_{j}} F_{j}-\sum_{l=1}^{N} n_{l} F_{\sim l}\right)$

Trzy wyrazy opisują odpowiednio: dyfuzję spowodowaną gradientami ułamka molowego $x_{i}$, ciśnienia $P$ oraz zewnętrznych sił $F_{j}$ działających na substancję j. Ponieważ prędkości dyfuzji są zdefiniowane w odniesieniu do średniej masowej prędkości, to jedynie $N-1$ współczynników wymaga wyliczenia, a równanie (8) musi zostać rozwiązane dla $N-1$ substancji. W plazmie, należy zmodyfikować współczynniki dyfuzji tak, aby uwzględniona została dyfuzja ambipolarna $[118,119]$. Ta $z$ kolei wzrasta, gdyż z powodu swojej mniejszej masy elektrony dyfundują szybciej niż jony, wzbudzając pole elektryczne, które przyspiesza jony, a spowalnia elektrony.

Rozwiązywanie równań (8) dla każdego składnika oraz obliczanie współczynników zwykłej dyfuzji dla każdej pary substancji i współczynników dyfuzji termicznej dla każdej substancji jest pracochłonne, dlatego zazwyczaj stosuje się metody uproszczone [103, $120]$. W tej pracy rozpatrywane są tylko te metody, które zostały zastosowane przy obliczaniu plazmy w oparach metalicznych.

Standardowym podejściem jest zgrupowanie substancji oparów metalicznych oraz gazu osłonowego, co oznacza, że potrzebne jest jedynie równanie na zachowanie ułamka masowego oparów metalu (6). Główną trudnością jest zastosowanie wzoru (6) do wyznaczenia $\overline{J_{M}}$.

Optymalnym podejściem jest metoda łącznego (efektywnego) współczynnika dyfuzji, początkowo rozwinięta dla gazów neutralnych [121], a następnie dla plazmy [84, 119, 122]. Przy założeniu istnienia stanu LTE metoda ta jest matematycznie równoważna pełnemu obliczeniu wieloskładnikowej dyfuzji dla mieszanin gazów mononuklearnych, które nie reagują ze sobą. Wymaganie dotyczące gazów mononuklearnych niewchodzących w reakcje oznacza, że gaz jest równoważny pierwiastkowi chemicznemu. Dyfuzyjny strumień masy oparów metalicznych można wówczas zapisać następująco:

$\overline{\mathrm{M}}=\frac{n^{2}}{\rho} \overline{m_{\mathrm{M}}} \overline{m_{\mathrm{G}}}\left(\overline{D_{\mathrm{MG}}^{x}} \nabla \overline{x_{\mathrm{G}}}+\overline{D_{\mathrm{MG}}^{P}} \nabla \ln P+\overline{D_{\mathrm{MG}}^{E}} \overline{\mathrm{E}}\right) \overline{D_{\mathrm{MG}}^{T}} \nabla \ln T$

gdzie: $\overline{m_{\mathrm{M}}}$ i $\overline{m_{\mathrm{G}}}$ średnie masy ciężkich substancji oparów metalicznych i gazu osłonowego, $\overline{x_{\mathrm{G}}}$ - suma ułamków molowych składników gazu osłonowego; $\nabla \overline{x_{\mathrm{G}}}=$ $-\nabla \overline{x_{M}}-$ współczynnik dyfuzji (w wyniku gradientów ułamków molowych), $\overline{D_{\mathrm{MG}}^{x}}-$ współczynnik dyfuzji ciśnieniowej ( $w$ wyniku gradientu całkowitego ciśnienia), $\overline{D_{\mathrm{MG}}^{p}}-$ łączny współczynnik dyfuzji (w wyniku przyłożenia zewnętrznego pola elektrycznego) $\overline{D_{\mathrm{MG}}^{E}}-$ współczynnik dyfuzji temperaturowej (w wyniku działania gradientu temperatury).
Współczynniki dyfuzji zawarte we wzorze (11) są liniowymi kombinacjami współczynników dyfuzji wieloskładnikowej [119, 122]. Pierwsze trzy współczynniki zależą tylko od współczynników dyfuzji zwyczajnej, natomiast $\overline{D_{M G}^{T}}$ zależy zarówno od współczynnika dyfuzji zwyczajnej jak i termicznej. Wartości łącznych współczynników dyfuzji zostały podane w literaturze dla wielu mieszanin gazów [90, 92, 94, 95, 123].

Wartości współczynników dyfuzji dla plazm zawierających opary metali, zostały podane przez Murphy'ego [103] oraz Aubretona i Elchingera [97] dla mieszaniny argonu i miedzi. Cressault i Gleizes [124] podali łączne współczynniki dyfuzji dla mieszanin argonu i miedzi oraz dla mieszanin miedzi, żelaza i srebra z powietrzem. Przedstawili także współczynniki dyfuzji spowodowanej polem elektrycznym dla mieszaniny powietrza z żelazem. Aubreton i Elchinger oraz Cressault i Gleizes zaprezentowali porównania współczynników dyfuzji dla mieszanin równych części oparów miedzi i argonu. Zgodność jest dobra, z rozbieżnościami poniżej 10\%. Różnice te można przypisać użyciu różnych całek zderzeniowych dla elastycznych zderzeń pomiędzy atomami i jonami, podobnie jak w przypadku lepkości. Metoda łącznego współczynnika dyfuzji została rozszerzona do plazmy o dwóch wartościach temperatury przez Rata [125] oraz dla mieszaniny argonu z miedzią [97]. Należy zwrócić jednak uwagę na to, że niektóre aspekty ich metod zostały zakwestionowane [96].

Na rysunku 9 przedstawiono współczynniki dyfuzji, obliczone dla różnych mieszanin argonu i oparów

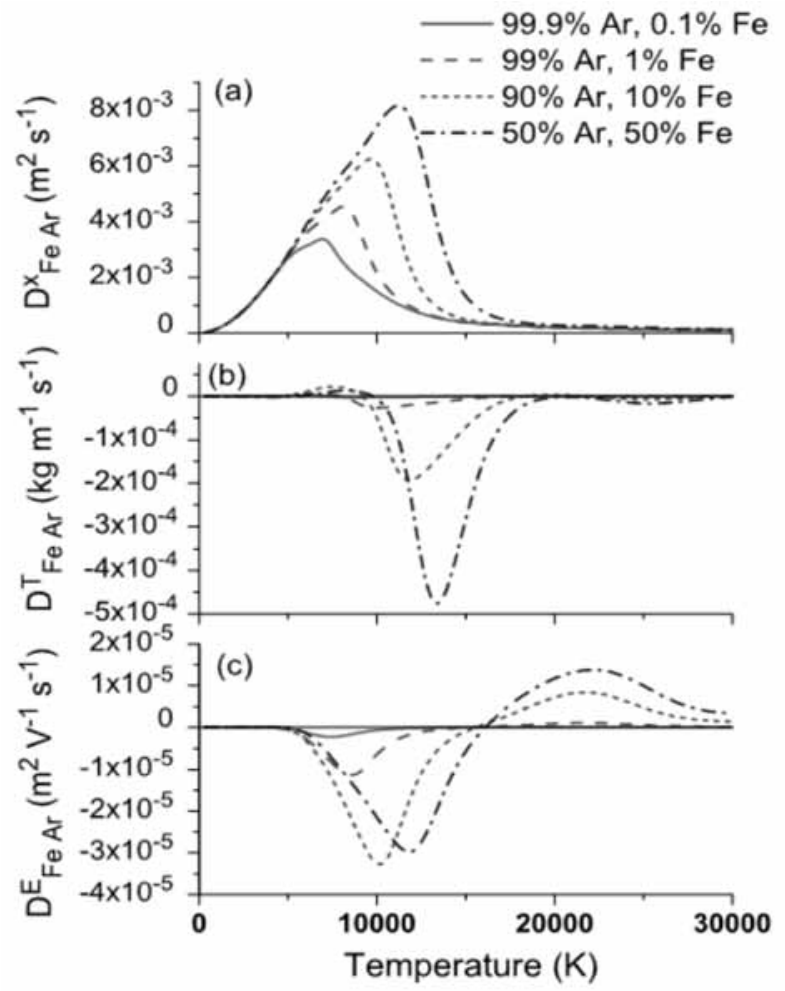

Rys. 9. Współczynniki dyfuzji zwyczajnej (a), temperaturowej (b) oraz spowodowanej polem elektrycznym (c) dla różnych mieszanin argonu i oparów żelaza. $(\% / \mathrm{mol})$

Fig. 9. Combined (a) ordinary, (b) temperature and (c) electric field diffusion coefficients for different mixtures of argon and iron vapour. $(\% / \mathrm{mol})$ 
żelaza. Wszystkie zależą od składu i temperatury. Łączny współczynnik dyfuzji jest niezależny od względnego stężenia tych dwóch gazów (w tym przypadku oparów żelaza i argonu), z wyjątkiem sytuacji, kiedy stężenie ma wpływ na stopień jonizacji gazów [90]. Opary żelaza są bardziej zjonizowane $w$ danej temperaturze, kiedy ich ułamek molowy jest mały. Duży kulombowski przekrój czynny dominuje w niższej temperaturze, obniżając średnią drogę swobodną i tym samym współczynnik dyfuzji. Łączne współczynniki dyfuzji temperaturowej oraz dyfuzji pochodzącej od pola elektrycznego zależą bezpośrednio od względnej koncentracji dwóch gazów i są większe wtedy, kiedy oba gazy są obecne w mniej więcej równych koncentracjach [90].

Łączne współczynniki dyfuzji ciśnieniowej nie zostały przedstawione, ponieważ dyfuzja ciśnieniowa jest znikoma w łukach spawalniczych z powodu małych gradientów ciśnienia. Kataforeza (dyfuzja spowodowana przyłożeniem pola elektrycznego) jest znacząca $\mathrm{w}$ przypadku składników znacznie różniących się masą i stąd oczekuje się, że będzie względnie mała dla mieszanin oparów żelaza i argonu. Łączne współczynniki dyfuzji pochodzącej od pola elektrycznego dla mieszanin argonu i żelaza są ok. jeden rząd wielkości mniejsze niż dla mieszanin argonu i helu lub wodoru [126]. Różnice te widać w wynikach otrzymanych przez modelowanie łuku. Kataforeza ma bardzo znaczący wpływ na skład w spawaniu łukowym GTAW w osłonie argonu z helem [126]. Schnick dowiódł, że wpływ kataforezy na dyfuzję oparów żelaza w spawaniu łukowym GMAW w argonie jest znikomy [72].

Do obliczenia członu na strumień masy $\bar{J}_{M}$ we wzorze (6), oprócz metody łącznych współczynników dyfuzji, użyto także innych, prostszych metod. Badania te zostały opisane i porównane dla różnych sytuacji w pracy [103]. W większości tych przypadków, strumień masy oparów metalicznych został obliczony przy użyciu wzoru:

$$
\bar{\sim} \overline{\mathrm{M}}=-\rho \overline{D_{\mathrm{MG}}} \nabla \overline{Y_{\mathrm{M}}}
$$

gdzie: $\overline{Y_{M}}$ - suma ułamków masowych oparów metalicznych; do wyznaczenia współczynnika dyfuzji $\overline{D_{\mathrm{MG}}}$ użyto wyrażenia przybliżonego. Tutaj skupimy się na zastosowaniu tych metod do dyfuzji oparów metalicznych w łukach spawalniczych.

Najprostszym oszacowaniem, jakim posłużono się w „przybliżeniu binarnego współczynnika dyfuzji” jest:

$$
\overline{D_{\mathrm{MG}}}=\mathscr{D}_{\mathrm{mg}}
$$

gdzie: $\mathscr{D}_{\mathrm{mg}}$ - binarny (podwójny) współczynnik dyfuzji pomiędzy atomami oparów metalu a atomami gazu osłonowego (lub molekuł dla gazów molekularnych).

Podejście takie pomija wpływ jonizacji i dysocjacji molekuł i tym samym jest dokładne tylko przy temperaturze ok. $5000 \mathrm{~K}$ lub niższej (przy której nie występuje ani jonizacja ani dysocjacja [103]). Strumień masy $\overline{J_{M}}$ obliczono ze wzoru (12).
Często stosowane jest „przybliżenie lepkościowe" uzyskane przy użyciu wyrażenia podanego przez Wilke'a [127], który oblicza lepkości gazów. Współczynnik dyfuzji jest obliczany pod względem lepkości $\overline{\eta_{\mathrm{M}}} \mathrm{i} \overline{\eta_{\mathrm{G}}}$ dwóch gazów:

$$
\overline{D_{\mathrm{MG}}}=\frac{(4 / \sqrt{2})\left(1 / \overline{m_{\mathrm{M}}}+1 / \overline{m_{\mathrm{G}}}\right)^{\frac{1}{2}}}{\left[\left({\overline{\rho_{\mathrm{M}}}}^{2} /{\overline{\beta_{\mathrm{M}}}}^{2}{\overline{\eta_{\mathrm{M}}}}^{2} \overline{m_{\mathrm{M}}}\right)^{\frac{1}{4}}+\left({\overline{\rho_{\mathrm{G}}}}^{2} /{\overline{\beta_{\mathrm{G}}}}^{2}{\overline{\eta_{\mathrm{G}}}}^{2} \overline{m_{\mathrm{G}}}\right)^{\frac{1}{4}}\right]^{2}}
$$

gdzie: $\overline{\rho_{I}}$ - gęstość gazu, I; $\overline{\beta_{I}}-$ stałe (zazwyczaj 1,385).

Strumień masy $\overline{J_{M}}$ został obliczony przy użyciu wzoru (12). To oszacowanie zostało nazwane „drugim oszacowaniem lepkości” w [103]. Opisane tam „pierwsze oszacowanie lepkości" nie zostało zastosowane dla plazmy oparów metalicznych, dlatego nie jest tutaj rozpatrywane. Na temat dokładności w oszacowaniu lepkości dla mieszanin gazów pisze Cressault [128].

Bakken and Gu [129] rozwinęli i zastosowali „przybliżenie quasi-podwójnego współczynnika dyfuzji”:

$$
\overline{D_{\mathrm{MG}}}=\left[\sum_{i=2}^{p}\left(1+Z_{i}\right) x_{i}\right]\left[\sum_{i=p+1}^{q}\left(1+Z_{i}\right) x_{i}\right] /\left(\sum_{i=2}^{p} x_{i} \sum_{j=p+1}^{q} x_{j} / \mathscr{D}_{i j}\right)
$$

gdzie: substancje $i=2, \ldots, p$ - składniki oparów metalicznych, substancje $i=p+1, \ldots, q$ - składniki gazów osłonowych, substancja 1 , która nie pojawia się explicite we wzorze (15) - to elektron.

W artykule [131] zaznaczono, ze strumień masy $\bar{J}_{M}$ powinien być wyznaczony na podstawie gradientu ułamka molowego. Posłużyło do tego następujące wyrażenie:

$$
\overline{\sim \mathrm{M}}=-\rho \overline{D_{\mathrm{MG}}} \nabla \overline{Y_{\mathrm{M}}}-\rho \overline{D_{\mathrm{MG}} Y_{\mathrm{M}} Y_{\mathrm{G}}} \nabla \ln \left(k_{\mathrm{M}} / k_{\mathrm{G}}\right)
$$

gdzie:

$k_{\mathrm{M}}=1+\left(\sum_{i=2}^{p} Z_{i} x_{i}\right) /\left(\sum_{i=2}^{p} x_{i}\right), k_{\mathrm{G}}=1+\left(\sum_{i=p+1}^{q} Z_{i} x_{i}\right) /\left(\sum_{i=p+1}^{q} x_{i}\right)(17)$

Niektórzy autorzy do obliczenia strumienia masy $\bar{J}_{M}$ we wzorze (6) posłużyli się jedynie wwspółczynnikiem dyfuzji. W dotychczas opublikowanych pracach $[18,123,132]$ został użyty łączny współczynnik dyfuzji bezpośrednio we wzorze (12), np.

$$
\overline{D_{\mathrm{MG}}}=\overline{D_{\mathrm{MG}}^{x}}
$$

Lepszym podejściem byłoby zastosowanie skróconej formy wzoru (11):

$$
\overline{J_{\mathrm{M}}}=\frac{n^{2}}{\rho} \overline{m_{\mathrm{M}} m_{\mathrm{G}}} \overline{D_{\mathrm{MG}}^{x}} \nabla \overline{x_{\mathrm{G}}}=-\rho \frac{\overline{m_{\mathrm{M}} m_{\mathrm{G}}}}{\bar{m}^{2}} \overline{D_{\mathrm{MG}}^{x}} \nabla \overline{x_{\mathrm{M}}}
$$

gdzie: $\bar{m}$ średnia masa wszystkich substancji.

Te dwa rozwiązania nazywa się: gradientem ułamka wagowego łącznego współczynnika dyfuzji zwyczajnej oraz gradientem ułamka molowego łącznego wspótczynnika dyfuzji zwyczajnej. 
Na rysunku 10 pokazano porównanie współczynnika dyfuzji określonego przy użyciu metody łącznego współczynnika dyfuzji oraz metod przybliżonych. Współczynniki są zgodne dla temperatury poniżej $6000 \mathrm{~K}$, w których występują głównie atomy argonu i żelaza. Przy wyższej temperaturze ważna staje się jonizacja, a przybliżone metody stają się mniej dokładne. Wpływ jonów i elektronów, które redukują współczynnik dyfuzji z powodu dużej wartość kulombowskiego przekroju czynnego, jest pomijany w przybliżeniu współczynnika dyfuzji podwójnej. Przybliżenie lepkościowe, które zostało rozwinięte dla mieszanin gazów neutralnych [127], zaniża współczynnik dyfuzji, z kolei przybliżenie quasibinarne prowadzi do zawyżenia jego wartości.

Aby umożliwić oszacowanie dokładności różnych metod w sytuacjach związanych ze spawaniem łukowym, obliczono dyfuzyjny strumień masy dla temperatury i rozkładu koncentracji oparów żelaza typowych dla drutu anody w spawaniu GMAW, oraz blisko anody będącej materiałem roboczym w spawaniu GTAW. Rozkłady są pokazane na rysunku 11. Temperatura blisko anody oraz stężenie oparów żelaza są większe dla GMAW.

Strumienie masy oparów żelaza obliczone dla rozkładów z rysunku 11 przedstawiono na rysunku 12. Metoda całkowitego łącznego współczynnika dyfuzji jest równoważna obliczeniu wieloskładnikowej dyfuzji, jeśli założono stan LTE i tym samym staje się punktem odniesienia, z którym inne oszacowania są porównywane.

W wysokiej temperaturze blisko drutu w spawaniu GMAW przybliżenie binarnego współczynnika dyfuzji znacznie zawyża strumień masy oparów żelaza (rys. 12a). Wszystkie inne oszacowania zaniżają strumień masy; najdokładniejsza jest metoda łącznego współczynnika dyfuzji zwyczajnej stosująca gradient ułamka molowego. Ułamek wagowy oraz ułamki molowe opa-

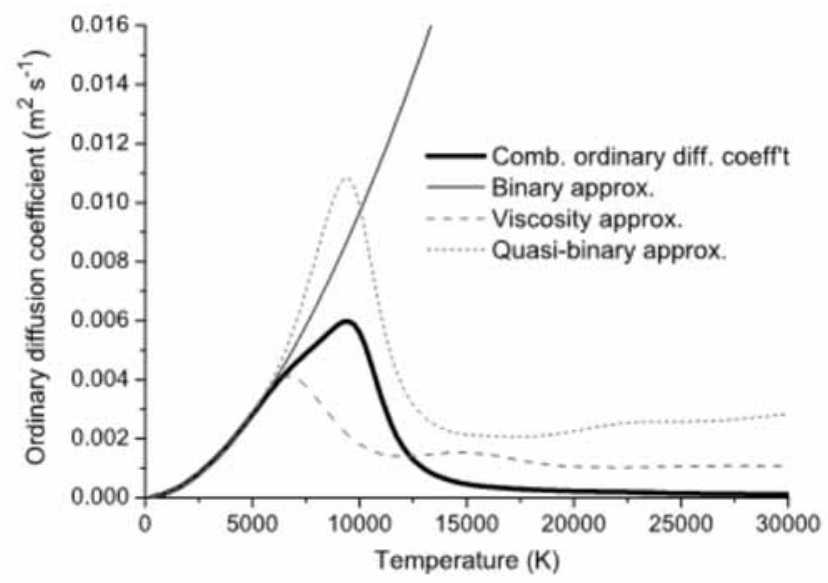

Rys. 10. Zależność współczynnika dyfuzji od temperatury dla mieszaniny $10 \%$ oparów żelaza i $90 \%$ argonu na mol. Wyniki podano dla wypadkowego współczynnika dyfuzji, dla przybliżenia binarnego współczynnika dyfuzji, przybliżenia lepkościowego oraz przybliżenia quasi-binarnego współczynnika dyfuzji

Fig. 10. Dependence of the ordinary diffusion coefficient, on temperature for a mixture of $10 \%$ iron vapour and $90 \%$ argon by mole. Results are given for the combined ordinary diffusion coefficient $D x$ $\mathrm{FeAr}$, the binary diffusion coefficient approximation, the viscosity approximation and the quasi-binary diffusion coefficient approximation rów metalicznych są prawie identyczne, więc różnica pomiędzy tymi obliczeniami łącznych współczynników dyfuzji zwyczajnej z powodu stosunku mas $\overline{m_{\mathrm{M}}} \overline{m_{\mathrm{G}}} / \bar{m}^{2}$ pojawia się we wzorze (19).

Temperatura i stężenia oparów metalicznych są niższe w spawaniu GTAW, jeśli anodą jest materiał spawany. Z rysunku $12 b$ widać, że większość metod przybliżonych mieści się w zakresie czynnika 2 w porównaniu z wynikami otrzymanymi metodą łącznego współczynnika dyfuzji. Jednakże wpływ ujemnych

a)
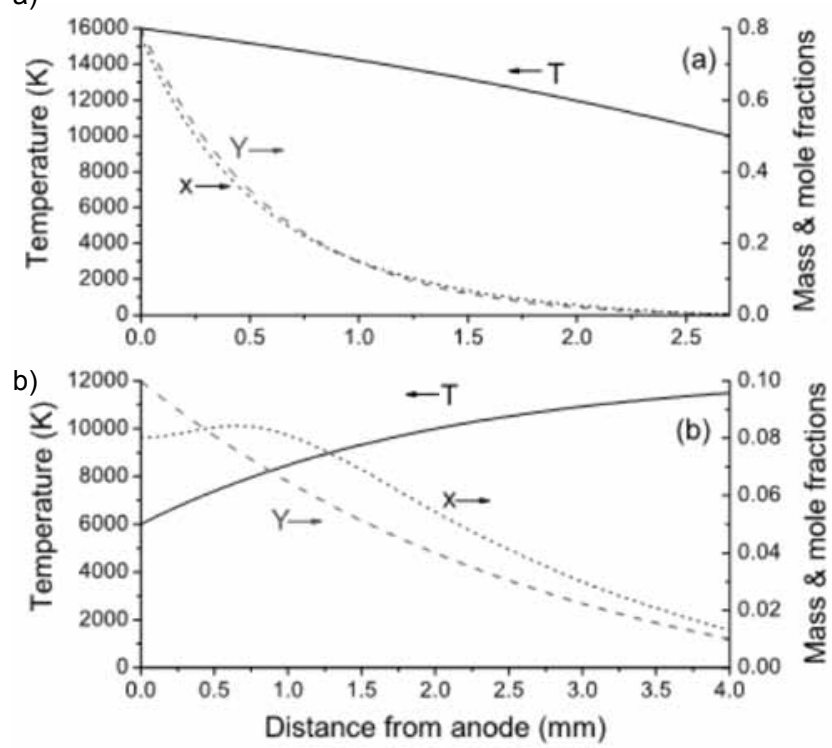

Rys. 11. Zależność temperatury i udziału oparów żelaza $\mathrm{x}$ oraz $\mathrm{Y}$ od odległości od anody w plazmie argon-żelazo. Zależność ta pokazuje typową ścieżkę dyfuzji oparów metalicznych z (a) drutu anody w spawaniu GMAW i anody materiału roboczego (b) w GTAW

Fig. 11. Dependence of temperature and iron vapour mole fraction $x$ and mass fraction $Y$ on distance from the anode in an argon-iron plasma, used to represent typical metal vapour diffusion paths from (a) a GMAW wire anode and (b) a GTAW workpiece anode

a)
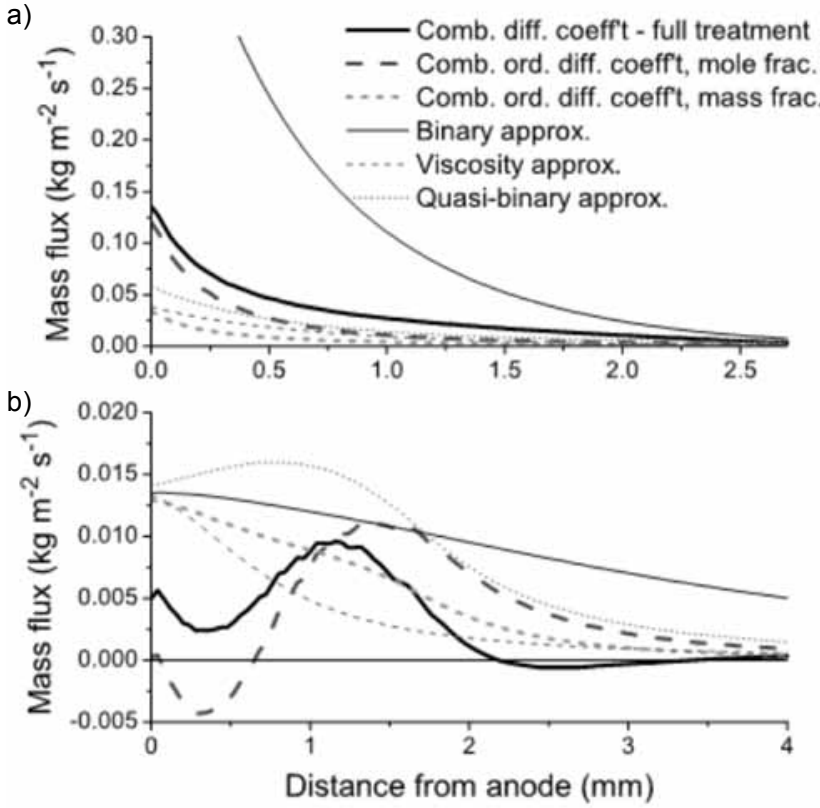

Rys. 12. Strumień masy oparów żelaza w zależności od odległości dla składu i temperatury pokazanych na rysunku 11

Fig. 12. Mass flux of iron vapour versus distance for the composition and temperature profiles shown in figure 11 
gradientów ułamka molowego blisko anody nie może być brany pod uwagę w metodach, w których gradient ułamka wagowego jest używany do obliczenia dyfuzyjnego strumienia masy. Strumień masy obliczony metodą łącznego współczynnika dyfuzji zwyczajnej przy użyciu gradientu ułamka molowego jest ujemny w tym obszarze. Z kolei wpływ tego wyrazu na gradient temperatury we wzorze (11) pokazuje, że strumień masy obliczony przy użyciu pełnej metody łącznego współczynnika dyfuzji w tym obszarze jest dodatni.

Z tych przykładów można wywnioskować, że dokładne uwzględnienie dyfuzji wymaga użycia pełnej metody łącznego współczynnika dyfuzji. Należy jednak zauważyć, że konwekcja jest często dominującą metodą przenoszenia oparów metalicznych w pewnych obszarach łuku, np. w centrum łuku poniżej drutu anody w spawaniu GMAW. Tak więc stosowanie przybliżeń przy uwzględnieniu dyfuzji w tych obszarach może dać zadowalające wyniki.

\section{Współczynniki emisji promieniowania}

Ogólnie wiadomo, że plazmy w pierwiastkach metalicznych promieniują znacznie silniej niż w zwykłych gazach osłonowych, takich jak argon, hel, azot czy wodór. Standardową metodą stosowaną w przypadku promieniowania plazm termicznych, takich jak łuki spawalnicze, jest metoda efektywnego (wypadkowego) współczynnika emisji [133]. Metoda ta ma szczególną zaletę, polegającą na tym, że chłodzenie łuku w wyniku emisji promieniowania może być opisane za pomocą zależnej od temperatury pojedynczej wielkości, współczynnika emisji promieniowania $U$. Inne metody uwzględnienia promieniowania w plazmach termicznych zostały omówione m.in. w [134]. Metoda charakterystyk cząstkowych ma szczególne zalety przy modelowaniu łuków występujących np. w wyłącznikach instalacyjnych, gdzie ważne jest ilościowe określenie zarówno absorpcji, jak również emisji promieniowania. Obliczenia wymaganych funkcji dla mieszanin sześciofluorku siarki oraz oparów miedzi zostały zaprezentowane przez Raynala [135]. Jednak w przypadku mieszanin gazów istotnych dla łuków spawalniczych, dane dotyczące efektywnego współczynnika emisji pojawiają się częściej w literaturze.

Obliczenie efektywnego współczynnika emisji jest trudnym zadaniem, szczególnie dla oparów metalicznych, dla których należy uwzględnić bardzo dużą liczbę linii emisyjnych. Istnieje znaczna rozbieżność pomiędzy danymi opublikowanymi w literaturze.

W obliczeniach założono, że plazma jest jednorodna, izotermiczna i znajduje się w stanie LTE. Najpierw oblicza się skład plazmy jako funkcję temperatury, ciśnienia i koncentracji różnych pierwiastków chemicznych. Efektywny współczynnik emisji promieniowania jest wtedy składową wszystkich linii widmowych oraz widma ciągłego, który wymaga uwzględnienia różnych składników. W niektórych obliczeniach bierze się również pod uwagę pasmowe widma molekularne. Współczynniki emisji mogą być obliczone dla plazmy optycznie cienkiej, wtedy można pominąć reabsorpcję linii promieniowania. Jednak w rzeczywistości plazma o ciśnieniu atmosferycznym nie może być rozpatrywana jako optycznie cienka dla wszystkich długości fali i linii spektralnych więc przy obliczaniu współczynnika emisji, trzeba brać pod uwagę reabsorpcję, co z kolei wymaga wyznaczenia kształtu linii. Opis użytych metod został podany w $[133,136,137]$.

Efektywne współczynniki emisji podane są dla danego promienia plazmy, przy modelowaniu plazmy termicznej ten promień jest równy przybliżonemu promieniowi silnie promieniującego obszaru łuku o wysokiej temperaturze. Dla łuku spawalniczego wynosi on ok. $1 \mathrm{~mm}$.

W celu oszacowania udziału linii widmowych w efektywnym współczynniku emisji Cram posłużył się uproszczoną metodą statystyczną [138]. Wyniki przedstawił dla plazmy w mieszaninach argonu i oparów żelaza. Zaletą tej metody jest to, że wymaga ona jedynie statystycznej próbki danych atomowych, jest jednak mniej dokładna niż inne, bardziej skomplikowane obliczenia. We wszystkich innych obliczeniach stosuje się standardowe metody, biorące pod uwagę emisję ciągłą oraz emisję dużej liczbie linii, choć istnieją oczywiście pewne różnice w danych źródłowych, ilości rozpatrywanych linii, czy metod użytych do obliczenia kształtu linii oraz innych przybliżeniach.

Gleizes [139] podał efektywne współczynniki emisji dla mieszanin oparów miedzi i argonu, azotu i sześciofluorku siarki oraz mieszanin oparów żelaza i argonu. Essoltani w swojej pierwszej pracy [140] przedstawił dane dla mieszanin oparów żelaza i argonu, a następnie dla mieszanin oparów żelaza, argonu i wodoru [141], a także mieszanin oparów żelaza, krzemu i aluminium z argonem [142]. Menart i Malik [143] przedstawili wyniki dla mieszanin oparów żelaza z argonem. Cressault [107] opublikował ostatnio dane dla mieszanin powietrza z oparami żelaza, miedzi i srebra. Aubrecht [144] podał efektywne współczynniki emisji dla plazm termicznych z oparami wolframu i powietrza z oparami miedzi.

Na rysunku 13 pokazano efektywne współczynniki emisji promieniowania dla mieszanin różnych oparów metalicznych w stosunku $1 \%$ mol w plazmie argonowej. Można zauważyć, że obecność zaledwie 1\% oparów metalicznych znacznie zwiększa emisję promieniowania przy wszystkich wartościach temperatury. Najsilniejsza jest emisja z oparów żelaza. Emisja promieniowania z lżejszych metali, takich jak aluminium i krzem, jest znacznie słabsza z powodu niewielu linii. W części 1 artykułu wspomniano, że obserwowany spadek temperatury na osi spowodowany obecnością oparów metalicznych w spawaniu GMAW był znacznie mniejszy dla aluminium niż dla oparów żelaza. Jest to prawdopodobniej konsekwencją słabszej emisji promieniowania z lżejszego metalu. 


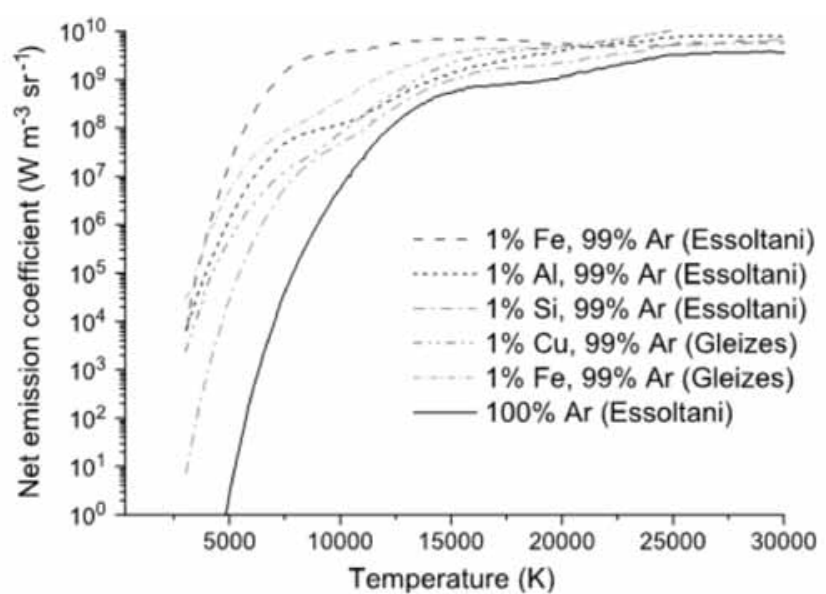

Rys. 13. Porównanie efektywnych współczynników emisji dla mieszanin argonu z $1 \%$ na mol oparów żelaza, miedzi, aluminium i krzemu oraz czystego argonu. Promień plazmy wynosi $1 \mathrm{~mm}$. Dane przytoczono $z[139,142]$

Fig. 13. Comparison of the net emission coefficients for mixtures of argon with $1 \%$ by mole of iron, copper, aluminium and silicon vapours, and pure argon. The plasma radius is $1 \mathrm{~mm}$. Data are from $[139,142]$

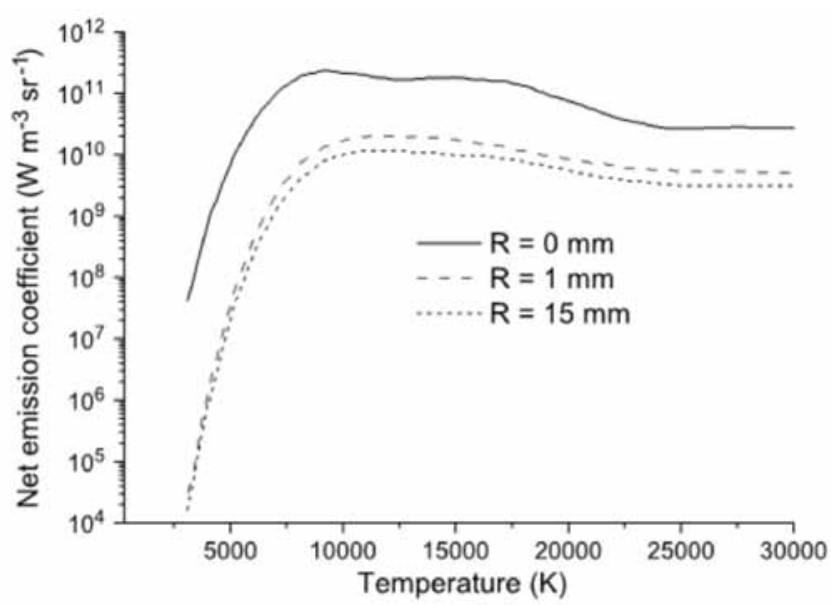

Rys. 14. Porównanie efektywnych współczynników emisji dla 100\% oparów żelaza przy różnych promieniach plazmy. Dane z pracy Essoltani [142]

Fig. 14. Comparison of net emission coefficients for $100 \%$ iron vapour, for different plasma radii. Data are from Essoltani et al [142]

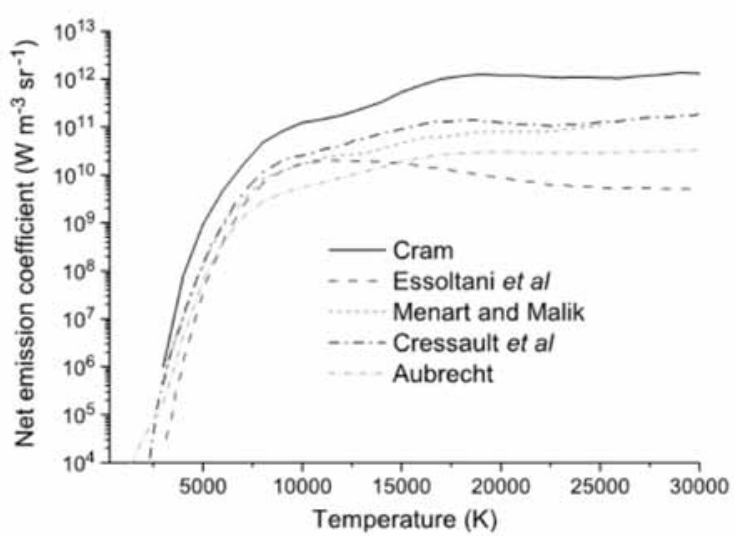

Rys. 15. Porównanie efektywnych współczynników emisji dla 100\% oparów żelaza w promieniu plazmy wynoszącym $1 \mathrm{~mm}$. Dane zaczerpnięto $z$ prac $[107,138,142,143,145]$

Fig. 15. Comparison of net emission coefficients for $100 \%$ iron vapour for a plasma radius of $1 \mathrm{~mm}$. Data are from [107, 138, 142, $143,145]$
Essoltani [142] nie przedstawił danych dla miedzi, więc dane dla mieszaniny argonu i miedzi zostały zaczerpnięte z pracy Gleizesa [139]. Aby umożliwić lepsze porównanie pomiędzy różnymi metalami, dane dla mieszaniny argonu z żelazem przytoczone z pracy Gleizesa również zostały przedstawione na rysunku 13. Można zauważyć, że emisja z mieszaniny argonmiedź jest słabsza niż obliczone przez obydwu autorów dla mieszaniny argon-żelazo. Współczynniki emisji żelaza określone przez Gleizesa są mniejsze niż wyokreślone przez Essoltaniego. Może to sugerować, że metody użyte przez Essoltaniego dają większe współczynniki emisji dla mieszaniny argon-miedź niż podane przez Gleizesa. Zatem, wydaje się prawdopodobne, że emisja z miedzi jest silniejsza niż z aluminium.

Cressault zauważył, że emisja z oparów żelaza była silniejsza niż emisja z oparów miedzi, która z kolei była silniejsza od emisji z oparów srebra [107]. Potwierdzono to zarówno dla oparów czystego metalu, jak i ich mieszaniny z powietrzem. Obliczenia Aubrechta [144] dla mieszanin z powietrzem wskazują, że emisja z oparów miedzi jest silniejsza niż z oparów wolframu w temperaturze powyżej $12500 \mathrm{~K}$, ale słabsza w niższej temperaturze.

Rysunek 14 przedstawia wpływ długości absorbcji na efektywny współczynnik emisji oparów żelaza. Wraz ze wszystkimi omówionymi powyżej oparami metali, absorpcja jest bardzo silna w początkowym $1 \mathrm{~mm}$, a powyżej tego promienia jest znacznie mniejsza. Jak wspomniano, w przypadku łuków spawalniczych zazwyczaj dla efektywnego współczynnika emisji wybiera się promień absorbcji $1 \mathrm{~mm}$. Wybór większego promienia nie powoduje jednak większej różnicy w obliczeniach.

Na rysunku 15 pokazano porównanie efektywnych współczynników emisji dla plazmy z oparami żelaza obliczonymi przez różnych badaczy. Wyniki Crama [138] zostały uzyskane za pomocą przybliżonej metody statystycznej i są znacznie wyższe niż inne (mimo że dane Crama dla argonu, przedstawione $w$ tej samej pracy, są zgodne $z$ większością innych wartości dla tego gazu). Wyniki Menarta i Malika [143] oraz Cressaulta [107] są w miarę zgodne, z kolei wyniki Aubrechta [145] wykazują podobną zależność temperaturową, ale są nieco mniejsze. Wyniki uzyskane przez Essoltaniego [142] zgadzają się z danymi Menarta i Malika oraz Cressaulta przy temperaturze dochodzącej do $11000 \mathrm{~K}$, ale są znacznie niższe w wyższej temperaturze. Dane Aubrechta nie zostały opublikowane, ale wyliczono je za pomocą metod podobnych do użytych w innych pracach [144, 146, 147].

Przy modelowaniu obliczeniowym wymagana jest znajomość współczynników emisji promieniowej dla szerokiego zakresu koncentracji oparów metali. Dane takie są zazwyczaj niedostępne, więc trzeba zastosować metodę interpolacji. Cressault pokazał, że prosta liniowa interpolacja oparta na ułamku molowym oparów metali daje satysfakcjonujące wyniki [128]. 
Schnick [72] przedstawił analize wpływu efektywnych współczynników emisji promienistej wybranych przy modelowaniu łuku spawalniczego GMAW. Koncentracja wagowa oparów żelaza wynosi $50-100 \%$ na osi łuku, co skutkuje temperaturowym minimum dla wszystkich przeanalizowanych zestawów efektywnych współczynników emisji. Temperatura na osi łuku przy 250 A jest silnie uzależniona od wyboru efektywnych współczynników emisji. Dla danych Aubrechta z promieniem absorpcji wynoszącym $1 \mathrm{~mm}$ temperatura mierzona $1,5 \mathrm{~mm}$ powyżej materiału roboczego wynosiła ok. $9000 \mathrm{~K}$, a dla tych samych danych Menarta i Malika temperatura wynosiła ok. $7000 \mathrm{~K}$. Dla współczynników emisji obliczonych przez Aubrechta, Menartaa i Malika oraz Crama przy zerowej absorpcji, temperatura na osi spadła do ok. $4000 \mathrm{~K}$. Bez wątpienia dokładne wartości efektywnych współczynników emisji są ważne w modelowaniu łuków w obecności oparów metalicznych.

Iwao badał wpływ reabsorpcji promieniowania w łuku spawalniczym GTAW [148]. Absorpcja promieniowania z czubka i dwóch stron każdej komórki obliczeniowej została obliczona przy użyciu współczynnika absorpcji dla mieszaniny argonu i oparów żelaza. Absorpcja promieniowania doprowadziła do znaczących zmian, włączając $\mathrm{w}$ to podgrzewanie łuku $\mathrm{w}$ obszarach o wysokiej koncentracji oparów metalicznych i szerszy profil temperatury łuku. Należy jednak zauważyć, że metoda pomijająca zależność absorpcji od długości fal jest jedynie przybliżona i może prowadzić do błędnych wyników.

\section{Obliczenie szybkości powstawania oparów metalicznych}

Dokładne określenie szybkości parowania oparów metalicznych z obszarów elektrody oraz innych powierzchni metalicznych, takich jak krople w przypadku GMAW, jest istotne w określeniu wpływu oparów metalicznych na łuk.

\section{Koncentracja równomierna}

Najprostszym przybliżeniem jest założenie, że koncentracja oparów jest równomierna w całym obszarze plazmy. Ze względu na to, że stężenie oparów będzie rosło z czasem, a obliczenia dotyczą stanu ustalonego, nie istnieje rzeczywiste powiązanie pomiędzy koncentracją oparów a szybkością odparowywania. Metoda, którą posłużyli się Gu [109] oraz Tashiro [149], jest przydatna jedynie do ogólnego oszacowania wpływu oparów metali.

\section{Stała szybkość odparowywania}

Kolejnym prostym oszacowaniem jest założenie stałej szybkości parowania z określonego obszaru elektrody. Tą metodą posłużył się Schnick w modelowaniu łuku GMAW $[72,150]$. Szybkość parowania została podana jako procent szybkości podawania drutu, a wybrane szerokość zostały uzasadnione przez odniesienie do danych eksperymentalnych. Szybkość parowania występuje jako wyraz źródłowy $S_{M}$ we wzorze (6) (otrzymane właściwe jednostki dzieli się przez szerokość sąsiedniej powierzchni). Ten sam źródłowy element powinien być także zawarty w równaniu na ciągłość masy (1). Metoda ta nie jest ogólne przyjęte i wymaga pewnych wyborów dotyczy elektrod, z których wydostają się opary. Niemniej jednak, jeśli szybkość parowania jest potwierdzona eksperymentalnie, metoda powinna przynieść sensowne wyniki.

\section{Metoda strumienia energii}

Celem tej metody, powszechnie stosowanej przy powstawaniu oparów oczyszczających, jest określenie strumienia masy oparów jako stosunku strumienia ciepła $q_{\text {inc }}$ docierającego do powierzchni metalu oraz entalpii koniecznej do odparowania metalu $\mathrm{H}$ :

$$
J_{\text {vap }}=q_{\text {inc }} / H_{\text {tot }}
$$

Podobnie jak w metodzie stałej szybkości odparowania, ta metoda zawiera człon źródłowy we wzorze (6). Metoda ta pomija chłodzenie metalu przez przewodnictwo cieplne, a zatem nadaje się jedynie do przypadku, gdy występuje bardzo duży strumień energii, który prowadzi do gwałtownego odparowywania. $Z$ tego powodu nie jest ona stosowana $w$ modelowaniu łuków spawalniczych, ale raczej $w$ modelowaniu wyłączników instalacyjnych $[15,16,18]$ oraz $w$ oczyszczaniu polimeru [151, 152]. Zazwyczaj zakłada się, że nie występują żadne obszary ciekłe $\mathrm{z}$ materiałem usuniętym bezpośrednio ze stanu stałego, więc $H_{\text {tot }}$ będzie zawierał zarówno utajone ciepło topnienia, jak i parowania.

Pracowano nad ulepszeniem tej metody w związku z erozją katod łuku próżniowego [153] i plazmowej ablacji polimerów [154, 155]. Metody te nie zostały zastosowane w obliczeniach koncentracji oparów metalicznych w łukach spawalniczych, ale można by posłużyć się nimi do polepszenia metod opisanych w następnym podrozdziale.

\section{Metody ciśnienia oparów}

Prawdopodobnie najszerzej stosowaną metodą służącą do określenia szybkości parowania oparów metalicznych jest metoda polegająca na obliczeniu ciśnienia oparów metalicznych $P_{\text {vap }}$ na granicy pomiędzy 
plazmą a ciekłym metalem wg równania ClausiusaClapeyrona:

$$
P_{\text {vap }}=P_{\text {atm }} \exp \left[\frac{-H_{\text {vap }}}{R}\left(\frac{1}{T_{1}}-\frac{1}{T_{\mathrm{b}}}\right)\right]
$$

gdzie: $P_{\text {atm }}$ - ciśnienie atmosferyczne, $H_{\text {vap }}$ - molowe ciepło parowania, $T_{1}^{\text {atm }}$ - temperatura ciekłego metalu, $T_{\mathrm{b}}$ - temperatura wrzenia metalu przy ciśnieniu atmosferycznym, $R$ - stała gazowa.

Zastosowano dwa sposoby uwzględnienia ciśnienia oparów w obliczeniach. Najczęściej stosowaną metodą jest zapewnienie warunków granicznych dla ułamka masowego oparów metalicznych na granicy, danego wzorem:

$$
Y_{\mathrm{M}}=\frac{P_{\text {vap }} M_{\mathrm{M}}}{P_{\text {vap }} M_{\mathrm{M}}+\left(P_{\mathrm{atm}}-P_{\text {vap }}\right) M_{\mathrm{G}}}
$$

gdzie: $M_{\mathrm{M}}$ - masa molowa metalu, $M_{\mathrm{G}}$ - masa molowa gazu plazmy $[63,156 \div 161]$.

Druga metoda polega na zastosowaniu równania Hertza-Knudsena-Langmuira do obliczenia strumienia masy związanego z ciśnieniem oparów, a następnie zastosowaniu jego wyniku jako członu źródłowego $S_{M}$ we wzorze (6) (po podzieleniu przez szerokość objętości kontrolnej sąsiadującej z powierzchnią, by otrzymać właściwe jednostki). W najprostszej postaci zapisane jest to wzorem:

$$
J_{\text {vap }}=\left(\frac{m_{\mathrm{M}}}{2 \pi k_{\mathrm{B}} T_{1}}\right)^{1 / 2} P_{\text {vap }}
$$

gdzie: $m_{M}$ - masa atomów oparów. Tą metodą posłużył się Haidar [162].

W bardziej skomplikowanym sformułowaniu

$$
J_{\text {vap }}=\left(\frac{m_{\mathrm{M}}}{2 \pi k_{\mathrm{B}}}\right)^{1 / 2}\left(\sigma_{\mathrm{e}} \frac{P_{\text {vap }}}{T_{1}^{\frac{1}{2}}}-\sigma_{\mathrm{c}} \frac{P_{\infty}}{T_{\infty}^{\frac{1}{2}}}\right)
$$

bierze się pod uwagę ciśnienie $P_{\infty}$ i temperaturę daleko od powierzchni oraz współczynnik odparowywania $\sigma_{e}$ oraz współczynnik kondensacji $\sigma_{c}$, który może wynosić mniej niż jeden [163]. Jednak takie sformułowanie nie było stosowane dla łuków spawalniczych. Jednym z powodów jest założenie, że $\sigma_{c}$ zmniejsza się pod wpływem przepływu z dala od powierzchni [164]. Ten przepływ jest szczególnie silny blisko elektrody w łukach spawalniczych GMAW. Ponadto, kwestią sporną jest również, czy szybkość odparowywania zmniejsza się poniżej poziomu danego wzorem (23) [165]. Jeśli tak jest, to zmniejszy się także chłodzenie związane z odparowywaniem kropli powstających na elektrodzie. Mogłoby to zwiększyć temperaturę kropli powyżej punktu wrzenia, prowadząc do wręcz wybuchowego parowania, które zrekompensowałoby redukcję.
Jak wspomniano, możliwe jest rozwinięcie jeszcze lepszych metod niż użytych w odniesieniu do ablacji polimerów. W metodach tych obliczono strumienie oparów, biorąc pod uwagę obszar izolujący przyległy do ciała stałego. W metodzie różniącej się od innych opisanych w literaturze, Gu $[131,166]$ traktował transport oparów krzemu z jeziorka spawalniczego jako tzw. zagadnienie Stefana, biorąc pod uwagę dyfuzję oparów przez zastygłą gazowo-obojętną powłokę. Innym możliwym podejściem, mającym zastosowanie w przypadkach, gdy temperatura ciekłego metalu jest bliska punktu wrzenia, jest obliczenie szybkości parowania przez przyrównanie $J_{\text {vap }} H_{\text {vap }} M_{\mathrm{M}}$ do wypadkowego strumienia ciepła dochodzącego do powierzchni ciekłego metalu [167].

Haidar podkreślił, jak istotne jest zawarcie członu źródłowego $S_{M}$ w równaniu na zachowanie masy [162]. Jest to ważne, ponieważ dzięki temu można wziąć pod uwagę wpływ powstawania oparów na przepływ w plazmie. W równaniu na energię jest potrzebny odpowiednik wyrazu źródłowego dla entalpii.

Metoda oparta na warunkach granicznych ułamka masowego (22) nie uwzględnia tych skutków i tym samym prawdopodobne zaniża prędkości w kierunku od źródła oparów oraz zaniża entalpię dostarczaną przez opary. Będzie to istotne dla dużych strumieni oparów, takich jakie pojawiają się w spawaniu GMAW (część 3 artykułu). W przypadku spawania GTAW, gdzie szybkości odparowywania są mniejsze, skutki też będą mniejsze, a metoda warunków granicznych prawdopodobnie będzie w miarę dokładna.

Zastosowanie równania Clausiusa-Clapeyrona w zasadzie jest ulepszeniem wprowadzonym do metody stałej szybkości odparowywania. Pozwala to na przeprowadzenie obliczenia koncentracji oparów metalicznych, włączając w to jej zależność od pozycji na granicy pomiędzy plazmą a ciekłym metalem. Jednak z tego powodu, że ciśnienie oparów bardzo silnie zależy od temperatury, konieczne staje się dokładne określenie temperatury powierzchni ciekłego metalu, co nie jest proste.

W literaturze opisane są różne metody traktowania anody w spawaniu GTAW, o różnym stopniu skomplikowania - poczynając od zwykłych oszacowań [156 -158], przez obliczenia pomijające topnienie elektrody [159], aż po samouzgadniające obliczenia uwzględniające przepływ w stopionym obszarze elektrody [160].

Kierunek przepływu ciekłego metalu w anodzie ma duży wpływ na kształt ciekłego jeziorka i może prowadzić do spłycenia jeziorka o względnie dużej powierzchni lub do jego pogłębienia przy mniejszej powierzchni. Jest to określone przez takie czynniki, jak: napięcie powierzchniowe ciekłego metalu, a w szczególności jego zależność od temperatury oraz gęstość prądu na powierzchni jeziorka [5]. Zatem w miarę dokładny model przepływu jeziorka jest warunkiem koniecznym do dokładnego obliczenia temperatury powierzchni i tym samym szybkości odparowywania metalu. 
Powierzchnia jeziorka. Większość modeli GTAW zakłada, że jest płaska natomiast w rzeczywistości zazwyczaj jest ona zaokrąglona z powodu wpływu ciśnienia łuku i napięcia powierzchniowego ciekłego metalu. Takie błędne założenie, może mieć także wpływ na przepływ w jeziorku, a także na położenie i właściwości obrazu łuku do anody [168]. Określenie zdeformowanej powierzchni można przeprowadzić przy użyciu tzw. metody objętości płynu (ang. volume-of-fluid) [169] lub metod, którymi wyznacza się kształt powierzchni równowagowej, biorąc pod uwagę różne siły $[170,171]$. Obie metody posłużyły do określenia profilu powierzchni jeziorka w spawaniu GTAW, ale zazwyczaj tylko w modelach, których obszar obliczeniowy nie zawierał łuku i nie brano pod uwagę powstawania oparów metalicznych [172, 173].

Przy obliczaniu temperatury powierzchni anody trzeba również wziąć pod uwagę utajone ciepło parowania. Należy także uwzględnić utajone ciepło syntezy, które będzie miało wpływ na granice pomiędzy ciekłym a stałym obszarem anody; standardowym podejściem jest metoda zastosowana przez Vollera i Prakasha [174].

W przypadku GMAW, większość oparów metalu wydobywa się $z$ drutu anody i kropli. W przypadku GTAW konieczne są obliczenia dla anody, w których bierze się pod uwagę strumień ciepła pomiędzy metalem a plazmą, utajone ciepło parowania oraz utajone ciepło łączenia na granicy pomiędzy obszarami stopionym i stałym. Pełne obliczenia wymagałyby śledzenia zmian w kształcie anody, kiedy krople powstają i odrywają się oraz ich ruchu przez łuk. Udało się osiągnąć pewien sukces, używając metody volume-of-fluid [175 $\div 179$ ], ale $w$ żadnym z tych przypadków nie uwzględniano wpływu oparów metalicznych [162]. Haidar, stosując metodę volume-of-fluid określił kształt anody, który następnie stał się punktem wyjścia do obliczeń dotyczących oparów metalicznych, ale obliczenia te niezostały potwierdzone.

\section{Literatura}

[2] Murphy A. B., Tanaka M., Tashiro S., Sato T., Lowke J. J.: A computational investigation of the effectiveness of different shielding gas mixtures for arc welding, J. Phys. D: Appl. Phys. 42115205 (2009).

[18] Nielsen T., Kaddani A., Zahrai S.: Modelling evaporating metal droplets in ablation controlled electric arcs, J. Phys. D: Appl. Phys. 34 2022-31 (2001).

[19] Yang F., Rong M., Wu Y., Murphy A. B., Pei J., Wang L., Liu Z., Liu Y.: Numerical analysis of the influence of splitter-plate erosion on an air arc in the quenching chamber of a low-voltage circuit breaker, J. Phys. D: Appl. Phys. 43 434011 (2010).

[36] Rat V., Murphy A. B., Aubreton J., Elchinger M-F., Fauchais P.: Treatment of non-equilibrium phenomena in thermal plasma flows, J. Phys. D: Appl. Phys. 41183001 (2008).

[72] Schnick M., Fssel U., Hertel M., Haessler M., Spille-Kohoff A., Murphy A. B.: Modelling of gas-metal arc welding taking into account metal vapour, J. Phys. D: Appl. Phys. 43 434008 (2010).

[84] Murphy A. B.: Thermal plasmas in gas mixtures, J. Phys. D: Appl. Phys. 34 R151-73 (2001).

[85] Chen X.: Personal communication (2005).

[86] Patankar S. V.: Numerical Heat Transfer and Fluid Flow, Washington. DC: Hemisphere (1980).

[87] Boulos M I., Fauchais P., Pfender E.: Thermal Plasmas: Fundamentals and Applications, vol. I. New York: Plenum, (1994).

[88] Chase M. W. Jr., Davies C. A., Downey J. R. Jr., Frurip D. J., McDonald R. A., Syverud A. N.: JANAF Thermochemical Tables 3rd edn., J. Phys. Chem. Ref. Data 14 Suppl. I (1985).

[89] Hirschfelder J. O., Curtiss C. F., Bird R. B.: Molecular Theory of Gases and Liquids 2nd edn., New York: Wiley (1964).

[90] Murphy A. B., Arundell C. J.: Transport coefficients of argon, nitrogen, oxygen, argon-nitrogen, and argon-oxygen plasmas, Plasma Chem. Plasma. Process. 14 451-90 (1994).

[91] Colombo V., Ghedini E., Sanibondi P.: Thermodynamic and transport properties in non-equilibrium argon, oxygen and nitrogen thermal plasmas, Prog. Nuci. Energy 50 921-33 (2008)
[92] Murphy A. B.: Transport coefficients of air, argon-air, nitrogen-air, and oxygen-air plasmas, Plasma Chem. Plasma Process. 15 279-307 (1995).

[93] Capitelli M., Colonna G., Gorse C., D'Angola A.: Transport properties of high temperature air in local thermodynamic equilibrium, Eur. Phys. J.D 11 279-89 (2000).

[94] Murphy A. B.: Transport coefficients of helium and argonhelium plasmas, IEEE Trans. Plasma Sci. 25 809-14 (1997).

[95] Murphy A. B.: Transport coefficients of hydrogen and argon-hydrogen plasmas, Plasma Chem. Plasma Process. 20 279-97 (2000).

[96] Colombo V., Ghedini E., Sanibondi P.: Two-temperature thermodynamic and transport properties of argon-hydrogen and nitrogen-hydrogen plasmas, J. Phys. D: Appl. Phys. 42 055213 (2009).

[97] Aubreton A., Elchinger M. F.: Transport properties in non-equilibrium argon, copper and argon-copper thermal plasmas, J.Phys. D: Appl. Phys. 36 1798-805 (2003)

[98] Andr P., Bussire W., Rochette D.: Transport coefficients of Ag-SiO ${ }_{2}$ plasmas, Plasma Chem. Plasma Process. 27 381403 (2007).

[99] Hulburt H. M., Hirschfelder J. O.: Potential energy functions for diatomic molecules, J. Chem. Phys. 9 61-9 (1941).

[100] Hulburt H. M., Hirschfelder J. O.: Correction, J. Chem. Phys. 351901 (1961)

[101] Rainwater J. C., Holland P. M., Biolsi L.: Binary collision dynamics and numerical evaluation of dilute gas-transport properties for potentials with multiple extrema, J. Chem. Phys. 77 434-47 (1982).

[102] Mostaghimi-Tehrani J., Pfender E.: Effects of metal vapor on the properties of an argon arc plasma, Plasma Chem. Plasma Process. 4 129-39 (1984).

[103] Murphy A. B.: A comparison of treatments of diffusion in thermal plasmas, J. Phys. D: Appl. Phys. 29 1922-32 (1996)

[104] Cressault Y., Gleizes A.: Thermodynamic properties and transport coefficients in $\mathrm{Ar}-\mathrm{H}_{2}$ Cu plasmas, J. Phys. D: Appl. Phys. 37 560-72 (2004).

[105] Hoffmann T., Baldea G., Riedel U.: Therrnodynamics and transport properties of metal/inert-gas mixtures used for arc welding, Proc. Combust. Inst. 32 3207-14 (2009). 
[106] Rapp D., Francis W. E.: Charge exchange between gaseous atoms and ions, J. Chem. Phys. 37 2631-45 (1962).

[107] Cressault Y., Hannachi R., Teulet P., Gleizes A., Gonnet J-P., Battandier J-Y.: Influence of metallic vapours on the properties of air thermal plasmas, Plasma Sources Sci. Technol. 17035016 (2008).

[108] Dunn G. J., Eagar T. W.: Metal vapors in gas tungsten arcs: II. Theoretical calculations of transport properties, Metall. Trans. A 17 1865-71 (1986).

[109] Gu L., Arntsberg A . E., Bakken J. A.: The influence of silicon vapour on the transport coefficients and the arc behaviour in an argon plasma, Proc. 10th Int. Symp. Plasma Chemistry ed U Ehlemann et al paper 1.1-6, Bochum, Germany, 4-9 August 1991.

[110] Abdelhakim H., Dinguirard J. P., Vacquie S.: The influence of copper vapour on the transport coefficients in a nitrogen arc plasma, J. Phys. D: Appl. Phys. 13 1427-38 (1980).

[111] Dassanayake M. S., Etemadi K.: Thermodynamic and transport properties of an aluminium-nitrogen plasma mixture, J. Appl. Phys. 66 5240-4 (1989).

[112] Cherny G. G., Losev S.A., Macheret S. O., Potapkin B.: Physical and Chemical Processes in Gas Dynamics: Cross Sections and Rate Constants vol. I, Reston, VA: AIAA (2002).

[113] Witko M., Beckmann H. O.: Ab initio MRD Cl calculations for ground and excited-states of $\mathrm{Cu}_{2}$ molecule, Mol. Phys. 47 945-57 (1982).

[114] Chervy B., Dupont O., Gleizes A., Kenek P.: The influence of the cross section the electron-copper atom collision on the electrical conductivity of $\mathrm{Ar}-\mathrm{Cu}$ and $\mathrm{SF}_{6}-\mathrm{Cu}$ plasmas, J. Phys. D: Appl. Phys. 28 2060-6 (1995).

[115] Scheibner K. F., Hazi A. U., Henry R. J.: 15th Int. Conf. Physics of Electronic and Atomic Collisions (Brighton, UK) ed. J. Geddes et al. (Amsterdam: North-Holland) (1987).

[116] Trajmar S., Williams W., Srivastava S. K.: Electron impact cross-sections for Cu atoms, J. Phys. B: At. Mol. Phys. 10 3323-33 (1977).

[117] Scheibner K. F., Hazi A. U., Henry R. J. W.: Electron-impact excitation cross sections for transitions in atomic copper, Phys. Rev. A 35 4869-72 (1987).

[118] Devoto R.S.: Transport properties of ionized monatomic gases, Phys. Fluids 9 1230-40 (1966).

[119] Murphy A. B.: Diffusion in equilibrium mixtures of ionized gases Phys. Rev. E 48 3594-603 (1993).

[120] Murphy A. B. Treatments of diffusion in thermal plasmas High. Temp. Mater. Process. 4 1-20 (2000).

[121] Murphy A. B.: Combined diffusion coefficients in equilibrium mixtures of dissociating gases, J. Chem. Phys. 99 1340-3 (1993).

[122] Murphy A. B.: Erratum. Diffusion in equilibrium mixtures of ionized gases [ Phys. Rev. E 48, 3594 (1993)], Phys. Rev. E 50 5145-6 (1994)

[123] Zhang J. L., Yan J. D., Murphy A .B., Hali M., Fang M. T. C.: Computational investigation of arc behavior in an auto-expansion circuit breaker contaminated by ablated nozzle vapour, IEEE Trans. Plasma Sci. 30 706-19 (2002).

[124] Cressault Y., Gleizes A .: Calculation of diffusion coefficients in air-metal thermal plasmas, J.. Phys. D: Appl. Phys. 43 434006 (2010)

[125] Rat V., Aubreton J., Elchinger M. F., Fauchais P., Murphy A. B.: Diffusion in two-temperature thermal plasmas, Phys. Rev. E 66056407 (2002).

[126] Murphy A. B.: Cataphoresis in electric arcs, J. Phys. D: Appl Phys. 31 3383-90 (1998)

[127] Wilke C. R.: A viscosity equation for gas mixtures, J. Chem. Phys. 18 517-9 (1950).

[128] Cressault Y., Teulet P., Gleizes A.: Thermal plasma properties in gas or gas-vapour mixtures, Proc. 17th Int. Conf. on Gas Discharges and their Applications (Cardiff, UK, 7-12 September 2008) ed. J. E. Jones (Cardiff: GD2008 Local Organizing Committee) str. 149-52 (2008).
[129] Gu L., Jensen R., Arntsberg A.E., Bakken J. A.: Study on silicon vapour contaminated argon arcs and the metal pools, Proc. 11th Int. Symp. Plasma Chemistry (Loughborough, UK, 22-27 August 1993) ed. J. E. Harry str. 222-7(1993).

[130] Bakken J. A.: Modelling of fluid flow, heat transfer and diffusion in arcs, J. High Temp. Chem. Process. 3 677-88 (1994).

[131] Gu L., Bakken J. A.: Mass, heat and momentum transfer at the plasma-metal pool interphase in a plasma arc reactor, Heat and Mass Transfer under Plasma Conditions, Proc. Int. Symp. (Cesme, Turkey, 1994) ed. P. Fauchais et al (New York: Begell House) str. 289-97 (1955).

[132] Ma Q., Rong M., Murphy A. B., Wu Y., Xu T., Yang F.: Simulation and experimental study of arc motion in a low-voltage circuit breaker considering wall ablation, IEICE Trans. Electron. E91-C 1240-8 (2008).

[133] Lowke J. J.: Predictions of arc temperature profiles using approximate emission coefficients for radiation losses, J. Quant. Spectrosc. Radiat. Transfer 14 111-22 (1974).

[134] Murphy A .B., Boulos M. I., Colombo V., Fauchais P., Ghedini E., Gleizes A., Mostaghimi J., Proulx P., Schram D. C.: Advanced thermal plasma modelling, High Temp. Mater. Process. 12 255-336 (2008).

[135] Raynal G., Vergne P. J., Gleizes A.: Radiative transfer in SF6 and SF6-Cu arcs, J. Phys. D: Appl. Phys. 28 508-15 (1955).

[136] Liebermann R.W., Lowke J. J.: Radiation emission coefficients for sulfur hexafluoride arc plasmas, J. Quant. Spectrosc. Radiat. Transfer 16 253-64 (1976).

[137] Gleizes A., Rahmani B., Gonzalez J. J., Liani B.: Calculation of net emission coefficient in $\mathrm{N}_{2}, \mathrm{SF}_{6}$ and $\mathrm{SF}_{6}-\mathrm{N}_{2}$ arc plasmas, J. Phys. D: Appl. Phys. 24 1300-9 (1991).

[138] Cram L. E.: Statistical evaluation of radiative power losses from thermal plasmas due to spectral lines, J. Phys. D: Appl. Phys. 18 401-11 (1985).

[139] Gleizes A., Gonzalez J. J., Liani B., Raynal G.: Calculation of net emission coefficient of thermal plasmas in mixtures of gas with metallic vapour, J. Phys. D: Appl. Phys. 26 1921-7 (1993).

[140] Essoltani A., Proulx P., Boulos M. I., Gleizes A.: Radiation and self-absorption in argon-iron plasmas at atmosphericpressure, J. Anal. At. Spectrom. 5 543-7 (1990).

[141] Essoltani A, Proulx P, Boulos M I oraz Gleizes A 1994 Effect of the presence of iron vapors on the volumetric emission of $\mathrm{Ar} / \mathrm{Fe}$ and $\mathrm{Ar} / \mathrm{Fe} / \mathrm{H}_{2}$ plasmas Plasma Chem. Plasma Process. 14 301-15.

[142] Essoltani A., Proulx P., Boulos M. I., Gleizes A.: Volumetric emission of argon plasmas in the presence of vapors of $\mathrm{Fe}$, Si and Al, Plasma Chem. Plasma Process. 14 437-50 (1994).

[143] Menart J., Malik S.: Net emission coefficients for argon-iron thermal plasmas, J. Phys. D: Appl. Phys.35 867-74 (2002).

[144] Aubrecht V., Bartlova M., Coufal O.: Radiative emission from air thermal plasmas with vapour of $\mathrm{Cu}$ or W, J. Phys. D: Appl. Phys. 43434007 (2010).

[145] Aubrecht V.: Personal communication (2010)

[146] Aubrecht V., Gross B.: Net emission coefficients of radiation in SF6 arc plasmas, J. Phys. D: Appl. Phys. 27 95-100 (1994).

[147] Aubrecht V., Bartlova M.: Net emission coefficients of radiation in air and $\mathrm{SF}_{6}$ thermal plasmas, Plasma Chem. Plasma Process. 29 131-47 (2009).

[148] Iwao T., Mori Y., Okubo M., Sakai T., Tashiro S., Tanaka M., Yumoto M.: Modelling of metal vapor in pulse TIG including influence of self-absorption, J. Phys. D: Appl. Phys. 43 434010 (2010)

[149] Tashiro S., Tanaka M., Nakata K., Iwao T., Koshiishi F., Suzuki K., Yamazaki K.: Plasma properties of helium gas tungsten arc with metal vapour, Sci. Technol. Weld. Join. 12 202-7 (2007). 
[150] Schnick M., Fssel U., Hertel M., Spille-Kohoff A., Murphy A. B.: Metal vapour causes a central minimumin arc temperature in gas-metal arc welding through increased radiative emission, J. Phys. D: Appl. Phys. 43 022001(2010).

[151] Kovitya P., Lowke J. J.: Theoretical predictions of ablation-stabilised arcs confined in cylindrical tubes, J. Phys. D: Appl. Phys. 17 1197-212 (1984).

[152] Li R., Li X., Jia S., Murphy A. B.: Study of different models of the wall ablation process in a capillary discharge, IEEE Trans. Plasma Sci. 38 1033-41 (2010).

[153] Beilis I. I.: Parameters of the kinetic layer of arc-discharge cathode region, IEEE Trans. Plasma Sci. 13 288-90 (1985).

[154] Keidar M., Boyd I. D., Beilis I. I.: On the model of Teflon ablation in an ablation-controlled discharge, J. Phys.D: Appl. Phys. 34 1675-7 (2001)

[155] Zaghloul M. R.: On the vaporization of Teflon and heated compound-materials in ablation-controlled arcs, J. Appl. Phys. 95 3339-43 (2004).

[156] Menart J., Lin L.: Numerical study of a free burning argon arc with copper contamination from the anode, Plasma Chem. Plasma Process. 19 153-70 (1999).

[157] Zhao G. Y., Dassanayabe M., Etemadi K.: Numerical simulation of a free-burning argon arc with copper evaporation from the anode, Plasma Chem. Plasma Process. 10 87-99 (1990).

[158] Lago F. Gonzalez J. J., Freton P., Gleizes A.: A numerical modelling of an electric arc and its interaction with the anode: I. The two-dimensional model, J. Phys. D: Appl. Phys. 37 883-97 (2004)

[159] Gonzalez J. J., Gleizes A., Proulx P., Boulos M.: Mathematical modelling of a free-burning arc in the presence of metal vapor, J. Appl. Phys. 74 3065-70 (1993).

[160] Yamamoto K., Tanaka M., Tashiro S., Nakata K., Yamazak K.,Yamamoto E., Suzuki K., Murphy A. B.: Metal vapour behaviour in thermal plasma of gas tungsten arcs during weIding, Sci. Technol. Weld. Join. 13 566-72 (2008).

[161] Yamamoto K., Tanaka M., Tashiro S., Nakata K., Yamazaki K., Yamamoto E., Suzuki K., Murphy A. B.: Numerical simulation of metal vapor behavior in arc plasma, Surf. Coat. Technol. 202 5302-5 (2008).
[162] Haidar J.: The dynamic effects of metal vapour in gas metal arc welding, J. Phys. D: Appl. Phys. 43165204 (2010).

[163] Barrett J., Clement C.: Kinetic evaporation and condensation rates and their coefficients, J. Colloid Interface Sci. 150 352-64 (1992).

[164] Cordes C., Rudolph B-E., Cammenga H. K.: Massen-und Wärmetransport bei der Verdampfung flüssiger Metalle Z., Metallk. 62 326-8 (1971).

[165] Haidar J.: An analysis of heat transfer and fume production in gas metal arc welding. III., J. Appl. Phys.85 3448-59 (1999).

[166] Gu L., Arntsberg A. E., Bakken J. A.: DC arc behaviour in mixtures of argon and metal (Si) vapour from a liquid metal anode, J. High Temp. Chem. Process. 1 (Suplement do nr. 3) 350-7 (1992).

[167] Lowke J. J.: Personal communication (2010).

[168] Murphy A .B., Tanaka M., Yamamoto K., Tashiro S., Sato T., Lowke J. J.: Modelling of thermal plasmas for arc welding: the role of shielding gas properties and of metal vapour, J. Phys. D: Appl. Phys. 42194006 (2009).

[169] Hirt C. W., Nichols B. D.: Volume of fluid (VOF) method for the dynamics of free boundaries, J. Comput. Phys. 39 20125 (1981).

[170] Kim J-W., Na S-J.: A study on the effect of contact tube-toworkpiece distance on weld pool shape in gas metal arc weIding, Weld. J. 74 141-52s (1995).

[171] Wu C. S., Chen J., Zhang Y. M.: Numerical analysis of both front- and back-side deformation of fully-penetrated GTAW weld pool surfaces, Comput. Mater. Sci. 39 635-42 (2007).

[172] Ko S., Farson D., Choi S., Yoo C. D.: Mathematical modeling of the dynamic behavior of gas tungsten arc weld pools, Metall. Mater. Trans. B: Process Metall. Mater. Process. Sci. 31 1465-73 (2000).

[173] Fan H. G., Tsai H. L., Na S. J.: Heat transfer and fluid flow in a partially or fully penetrated weld pool in gas tungsten arc welding, Int. J. Heat Mass Transfer 44 417-28 (2001).

[174] Voller V. R., Prakash C.: A fixed grid numerical modelling methodology for convection-diffusion mushy region phasechange problems, Int. J. Heat Mass Transfer 30 1709-19 (1987).

Część 1 artykułu opublikowano w numerze 1/2012 Przeglądu Spawalnictwa (str. 18-29). Część 3 artykułu zostanie opublikowana w późniejszym numerze miesięcznika.

Artykuł za zgoda autora i redakcji został przedrukowany z Journal of Physics D: Aplied Physics Vol. 43 (2010) str 1-31 (6 rozdziałów) 434001 (31pp) http://iopscience.iop.org/0022-3727/43/43/434001/

Prawa autorskie do artykułu posiada wydawca IOP Publishing Ltd, Dirac House, Temper Back, BRISTOL, BS1 6BE

Z języka angielskiego tłumaczyła Aleksandra Pytel. Korekta łłumaczenia mgr Witold Zawadzki (Uniwersytet Jagielloński).

\section{W następnym numerze}

\section{Ryszard Pakos}

Kwalifikowanie technologii spawania prętów do zbrojenia betonu

\section{Ryszard Pakos}

Wpływ metody cięcia na właściwości stalowej krawędzi cięte

\section{Marzena M. Lachowicz}

Odporność korozyjna połączeń spawanych wykonanych na stopie AW 7020 